\title{
4 Die Lebendigkeit des Todes: DARK SOULS
}

\section{Die Dialektik der Schwärze}

Eine dunkle Seele ... was ist das eigentlich ${ }^{1}$ Der Ausdruck erweckt eine Vielzahl an Assoziationen, die um unheimliche Orte und ihre Bewohner kreisen: verfallene Friedhöfe und Grüfte, die Ruinen von Herrenhäusern und Burgen, verwunschene Wälder, überwucherte Gärten und die kargen Weiten infernalischer Einöden - allesamt durchstreift von Verdammten und Verlorenen; bösen Geistern und Dämonen; ruhelosen Wesenheiten, die, weder lebendig noch tot, sich im Nichts zwischen Diesseits und Jenseits gefangen sehen.

Tatsächlich sind die skizzierten Assoziationen geeignet, so etwas wie einen, gewiss unvollständigen, Katalog der Topografie und des Personals von Hidetaka Miyazakis DARK-SOULS-Trilogie zu erstellen. ${ }^{2}$ Schließlich handelt es sich hier um Spiele, die - wie man mit Gareth Damian Martin sagen könnte besessen sind vom Thema des Todes und aus dieser Präokkupation heraus eine ewig sterbende Welt erschaffen. ${ }^{3}$ Doch das Bild der dunklen Seele eröffnet noch andere Denkräume, die jenseits der vielleicht allzu treffenden, allzu erwartbaren Assoziationen verortet sind.

Folgt man Alain Badiou und seiner „Dialektik der Schwärze“, dann ist es das unhintergehbare Kennzeichen dieser Nicht-Farbe, dass sie zugleich einen

1 Die in diesem Kapitel vorgestellte DARK-SOULS-Analyse ist in stark gekürzter - und auf einige Kernthesen konzentrierter - Form als Einzelstudie veröffentlicht worden. Vgl. Daniel Illger: Das Leben mitten im Tod. DARK SOULS und das gebieterische „Jetzt!“. In: Rudolf Thomas Inderst/Pascal Wagner/Christof Zurschmitten (Hg.): Prepare to die! DEMON SOULS, DARK SOULS und BLOODBORNE. Glückstadt 2019, S. 71-88.

2 Wenn es um das Medium Videospiel geht, ist die Zuweisung einer eindeutigen Autorenschaft natürlich eine sehr heikle Sache. Im Fall von Miyazaki jedoch mag dergleichen angemessen sein. Keza MacDonald schreibt: „Where most games are composite creations, influenced and guided by hundreds of pairs of hands, DARK SOULS' singularity owes much to Miyazaki's detailed, hands-on-style of direction. [...] He often defers to his team when talking about how Souls was made, but - and this is not to diminish the role of any other talented people who worked on the game - his overall aesthetic and thematic sensibilities filter down through the team and into the tiniest nuances of DARK SOULS. Simply put, without Miyazaki there would be no DARK SOULS at all.“ Keza MacDonald: Final Boss. Understanding DARK SOULS' Creator. In: dies./Jason Killingsworth (Hg.): You Died. The DARK SOULS Companion. Glasgow 2016, S. 138-149, hier: S. 139.

3 Vgl. Gareth Damian Martin: An Obituary for the Architecture of DARK SOULs' Eternally Dying Land. Apocalypse Forever. In: www.eurogamer.net, 18. Juni 2017, https://www.eurogamer. net/articles/2017-06-18-an-obituary-for-the-architecture-of-dark-souls-eternally-dying-land [letzter Zugriff: 12.05.2020].

כ Open Access. (C) 2020 Daniel Illger, publiziert von De Gruyter. (cc) BY-NC-ND Dieses Werk ist lizenziert unter der Creative Commons Attribution-NonCommercial-NoDerivatives 4.0 International Lizenz.

https://doi.org/10.1515/9783110695380-004 
Mangel und einen Überschuss symbolisiert. ${ }^{4}$ Das radikal Dunkle zeichnet sich dadurch aus, dass in ihm ein Zuviel und ein Zuwenig einander begegnen, einander bedingen, sodass eins nicht mehr ohne das andere gedacht werden kann. Was das bedeuten mag, veranschaulicht Badiou in einer Reihe von Vignetten, die vermeintlich disparate Phänomene in jener Dialektik zusammenbinden.

Wie zum Beispiel verhält sich das Schwarz der Tinte zum Weiß des Papiers? Es ist dies eine Frage, die dem kleinen Alain, als er ein Schulkind war, offenbar Anlass zu größten Quälereien bot - sah sich der Junge doch einerseits bedroht vom verschlingenden Weiß des Papiers, einem Insignium der Gedankenleere, der Unwissenheit, des Scheiterns; kaum weniger bedrohlich war aber andererseits der allzu eilige Gedankenflug, der den Schüler dazu verleitete, im Schreibrausch ein Übermaß an Tintenflecken zu produzieren, was dem Lehrer seinerseits Anlass zu einer strengen Mahnung war. Badious Schlussfolgerungen, was die „complexitiy of writing“ betrifft, lesen sich wie folgt:

There must be black on white, but not too much of it! With just the right amount of it, when it's controlled and shapely, it's the occasion of salvation. But when there's too much of it, when it's out of control and shapelss, it comes close to Hell. ${ }^{5}$

Oder nehmen wir das Ultraschwarz - l'outrenoir - des französischen Malers Pierre Soulages. Für Badiou stellt dieses Schwarz nicht die Abwesenheit von Licht dar, sondern die Grundlage für „a light other than light“6, sodass die Bilder Soulages', welche sich seiner bedienen, eben nicht Nichts zeigen, sondern im Gegenteil ,the painterly landscape of a world without borders and of an infinite potential of perspectives and meanings“. ${ }^{7}$ Oder das Schwarz der Blumen. Es handelt sich hierbei um ein geheimes, ein unterirdisches Schwarz: das Schwarz des Wurzelwerkes. Überaus roh, wild und gewalttätig ist es: allverschlingend, in einen ewigen Kampf verstrickt. Gerade darin und daraus aber erzeugt das Wurzelschwarz ,the flowers of shimmering life and constant, comforting color". ${ }^{8}$ Sodass das Schwarz des Todes mit einem Schwarz des

4 Vgl. Alain Badiou: Black. The Brilliance of a Non-color. Cambridge/Malden 2017, S. 77. Französisches Original: Alain Badiou: Le noir. Éclats d'une non-couleur. Paris 2015, S. 43.

5 Badiou: Black, S. 17. „[...] il ne faut sur le Blanc que du noir, mais point trop n'en faut! À bonne dose, contrôlé, informé, il est le lieu du Salut. Excessif, hors contrôle, informe, il touche à l'Enfer." Badiou: Le noir, S. 23.

6 Badiou: Black, S. 41. „[...] d'une autre lumière que la lumière“. Badiou: Le noir, S. 50 [Herv. i. O.].

7 Badiou: Black, S. 44. „[...] le paysage pictural d'un monde sans frontières, et d'une virtualité infinie des perspectives et des significations“. Badiou: Le noir, S. 53.

8 Badiou: Black, S. 85. „[...] les fleurs de la vie chatoyante, la permanente couleur consolatrice“. Badiou: Le noir, S. 100. 
Lebens einergeht; was übrigens, folgt man Badiou, etwa auch für die Semantik des Flaggenschwarz gilt, das ein dem Tod geweihtes Leben meinen kann (die Piraten auf hoher See oder die „desert pirates“ des IS), oder aber die Vision „albeit shallow and simplistic but nontheless vibrant and fraternal“9 - der Hoffnung auf eine versöhnte Welt (die Anarchisten). ${ }^{10}$

All diesen Beispielen ist gemein, dass das Schwarz eine ebenso spannungsreiche wie unauflösliche, kurzum dialektische, Verbindung zu seinem Gegenspieler, dem Weiß, eingeht. Himmel und Hölle, Leben und Tod, Vollendung und Scheitern, Erfüllung und Versagung sind nicht voneinander zu trennen, wenn das Geheimnis des Schwarz in Rede steht. Wobei Schwarz und Weiß nicht eindeutig bestimmten Valenzen zugeordnet sind; so findet die kindliche Angst vor unbewältigt-bedrohlichem (Schul-)Wissen ihr Symbol im Weiß des Papiers. Auch ist $\mathrm{zu}$ beachten, dass sich die vermeintlich oppositionellen Pole, etwa Leben und Tod, im Reich der Schwärze einander angleichen, indem sie in ihrem Zuviel und Zuwenig auf den jeweiligen Widersacher verweisen; so wie die überbordende, farbpralle Vielfalt der Blumen und der bittere, erbarmungslose Überlebenskampf im Wurzelreich sich wechselseitig erzeugen. Die Sache wird noch weiter kompliziert dadurch, dass das Schwarz nicht nur mit dem Weiß, sondern zudem mit gewissen Farben (also echten, anständigen Farben, die den Namen verdienen) eine ähnlich gewundene Beziehung eingeht. So etwa mit dem Rot, das sich - man denke an Stendhals Roman Le rouge et le noir (1830) - als „the active essence“ des Schwarz offenbart und immer mehr oder weniger das Rot des Blutes ist, ${ }^{11}$ zugleich jedoch in der Vexillologie das Schwarz zu erheben vermag: als Rot des Kommunismus. ${ }^{12}$

Diese Einzelheiten scheinen mir im gegebenen Zusammenhang weniger bedeutsam. Wichtig ist allerdings, dass die beschriebene, paradoxe Dialektik der Schwärze ausdrücklich auch für die menschliche Seele gilt. ${ }^{13}$ Für Badiou ist die Dunkelheit der Seele etwas, das sich stets ereignishaft enthüllt, wenn plötzlich deutlich wird, wozu die Spezies, der man angehört, im Allgemeinen und Speziellen fähig ist und inwieweit das Grausige, das da zutage tritt, das

9 Badiou: Black, S. 49. „[...] une vision, sommaire ou brutale, mais effervescente et fraternelle, de 1'espérance en un monde réconcilié“. Badiou: Le noir, S. 58.

10 Vgl. Badiou: Black, S. 45-50.

11 Vgl. Badiou: Black, S. 56. „[...] essence active“, Badiou: Le noir, S. 68.

12 Vgl. Badiou: Black, S. 50 u. S. 86. Vgl. Badiou: Le noir, S. 60 u. S. 116.

13 Es soll nicht unerwähnt bleiben, dass Susan Spitzer, Badious Übersetzerin, es für angemessen und sogar notwendig erachtet, das französische „noir“ eben auch als „dark“ ins Englische zu übertragen. Ich erlaube mir deshalb, den Geltungsbereich von Badious Überlegungen, die vorderhand nur die „schwarze Seele“ betreffen, auf die „dunke Seele“ im Allgemeinen auszuweiten. Vgl. Susan Spitzer: Translator’s note. In: Badiou: Black, S. vii-viii, hier: S. vii. 
eigene Leben betreffen könnte. Schwarz gilt dann als die (Nicht-)Farbe „of treacherous, murderous, incestous souls“; darüber hinaus ist es „the color, or the sinister absence of color, of groundless accusations, of rampant slander“. ${ }^{14}$ Die schwarze Seele verbindet sich in ihrer Schwärze also mit Vorstellungen von Unreinheit, von Verderbtheit, wohingegen ihre Gegenspielerin, die weiße Seele, der Reinheit zugehört.

Doch die Dialektik der Schwärze sorgt dafür, dass diese vermeintlich klaren Verhältnisse bald schon sich verunklaren: Denn es erweist sich, meint Badiou, dass die weiße Seele ihre eigene Reinheit letztlich ihrer Unwissenheit und Ahnungslosigkeit verdankt. Die „most physical form“ der Reinheit sei die weibliche Jungfräulichkeit und selbige symbolisiere „that form of weak negation that is ignorance. Young girls and brides are pure only insofar as they don't know what darkness the soul is capable of."15

Diese Argumentation ist sicherlich sehr einsinnig, insofern sie den „dark Phallus“ als Ziel jeglichen Begehrens und Strebens setzt und beispielswiese ignoriert, dass es eine Entscheidung zur Jungfräulichkeit geben kann, bei Frauen und bei Männern, die nichts mit blauäugiger Verhuschtheit oder blaustrümpfiger Verklemmtheit zu tun hat, sondern im Gegenteil aus einem Wissen um die Welt und die menschliche Seele in allen ihren Farben herrührt. ${ }^{16}$

Was mich allerdings bezüglich der DARK-SOULS-Trilogie interessiert, ist die Anbindung der schwarzen Seele an eine Wissensordnung. Badiou drückt das wie folgt aus: „All knowledge is knowledge of black, which happens by surprise. “17 In dieser Perspektive ist Wissen also immer an das Verräterische, Mörderische und Inzestuöse gebunden. Das heißt, der Grund der Wahrheit ist ein schwarzer Ab-Grund - etwas anderes gibt es nicht. Wenn wir diesen Kerngedanken der „Dialektik der Schwärze“ mit jenem zweiten verbinden, der im Schwarz immer einen Mangel und zugleich einen Überschuss erkennt, dann gewährt uns das einen ersten Einblick in das rätselhafte Faszinosum von DARK SOULS.

14 Badiou: Black, S. 37. „[...] des âmes traîtresses, meurtrières et incestueuses, est par extension la couleur, ou la sinistre absence de couleur, des accusations sans fondement, des calomnies rampantes“. Badiou: Le noir, S. 46.

15 Badiou: Black, S. 38. „[...] cette forme de négation faible qu'est l'ignorance. La jeune fille, 1'épousée, ne sont pures que d'ignorer la noirceur dont l'âme est capable.“ Badiou: Le noir, S. 47.

16 Vgl. Badiou: Black, S. 39. Vgl. Badiou: Le noir, S. 48.

17 Badiou: Black, S. 39. „Tout savoir est savoir du noir, tel qu'il advient par surprise.“ Badiou: Le noir, S. 48. 


\section{Ein Ineinander von Qual und Genuss}

Aber der Reihe nach. Ich will mit einigen sehr allgemeinen Überlegungen zu DARK SOULS beginnen. ${ }^{18}$ Worum geht es hier? Und mit was für einer Art Spiel haben wir es eigentlich zu tun?

Andreas Inderwildi umreißt die narrative Grundkonstellation von DARK SOULS wie folgt:

The intro of DARK SOULS presents a creation myth or cosmogony in which the element of fire, so central to many historical cosmologies, is seen as some sort of ,creative spark' that makes possible the world as the player of DARK SOULs knows it by bringing ,disparity" between heat and cold, light and dark, life and death. The sun, with its symbolic presence as Lord Gwyn, also plays a major role. In fact, the player's quest is to kill the ailing sun god in order to save Lordran from cosmic stagnation; the result of Gwyn's attempts to stave off the inevitable heat death of the universe. ${ }^{19}$

Diese Darstellung neigt offensichtlich der Abstraktion zu. Darin verdeutlicht sie aber etwas, das in der Spielerfahrung selbst, wie wir noch sehen werden, leicht aus dem Blick gerät: Im Grunde spinnt DARK SOULS ein Fantasy-Garn mit dickem Faden. Wie so oft haben wir es mit einer gefallenen Welt $\mathrm{zu}$ tun, die von einer großen Dunkelheit bedroht wird. Da braucht es jemand, der zur Rettung schreitet,

18 Wenn ich im Folgenden von DARK SOULS spreche, meine ich die drei Spiele, die tatsächlich unter diesem Namen firmieren: DARK SOULS (From Software, 2011) beziehungsweise DARK SOULS: REMASTERED (From Software, 2018), DARK SOULS II (From Software, 2014) und DARK SOULS III (From Software, 2016). Der Einfachheit halber werde ich den ersten Teil der Trilogie, dem die meisten der von mir angeführten Beispiele entstammen, in der Regel als DARK SOULS adressieren und nur von DARK SOULS I, DARK SOULS II und DARK SOULS III reden, wenn es darum geht, Spezifika der einzelnen Spiele zu behandeln

Ist im Umfeld des Spielejournalismus oder der Game Studies von der DARK-SOULS-Reihe oder dem DARK-SOULS-Franchise die Rede, werden häufig auch DEMON'S SOULS (From Software, 2009), der unmittelbare Vorläufer von DARK SOULS, und BLOODBORNE (From Software, 2015) ein Spiel, das einige grundlegende Mechaniken von DARK SOULS in die viktorianisch anmutende, von Kosmischem Horror à la Lovecraft und allerlei gotischen Schrecknissen heimgesuchte Stadt Yharnam überträgt - miteinbezogen (weshalb man dann manchmal auf das Kompositum SOULSBORNE zur Benennung der Reihe zurückgreift).

19 Andreas Inderwildi: How DARK SOULS, BLOODBORNE and More Imagine the Cosmos. Shining a Light on the Stars. In: www.eurogamer.net, 30. Januar 2018, https://www.eurogamer.net/ articles/2018-01-30-how-dark-souls-bloodborne-and-more-imagine-the-cosmos [letzter Zugriff: 12.05.2020]. Demgemäß besteht die „zentrale Unversöhnlichkeit von DARK SOULS“ für Inderwildi „nicht zwischen Ewigkeit und Vergänglichkeit oder Zyklen und linearem Zeitverlauf, sondern zwischen Fluss und Stagnation“. Vgl. Meier-Inderwildi: Zwischen Ritual, Mythos und Geschichte, S. 123. Bezogen auf die Spielerfahrung kommt dieser Gedanke, scheint mir, der These nahe, die ich im Folgenden zu entwickeln suche. 
und auch in diesem Spiel fällt diese Rolle den Spielerinnen und Spielern zu. Dass die Sache vielleicht doch etwas komplizierter ist, wird deutlich, wenn wir uns vergegenwärtigen, dass Hidetaka Miyakazi den Spieler nicht gegen einen dunklen Herrscher dieser oder jener Provenienz in Stellung bringt, sondern gegen den gottgleichen Sonnenkönig Gwyn. Daraus lässt sich ableiten, dass die Poetik von DARK SOULS unter anderem auf die Verkehrung der Wertigkeiten von Licht und Dunkelheit abhebt. Wofür ebenfalls spricht, dass es sich bei dem Avatar - was Inderwildi an dieser Stelle unerwähnt lässt - keineswegs um eine fürs Heldentum prädestinierte Persönlichkeit handelt, sondern um einen Untoten beziehungsweise eine Untote, der oder die zu Beginn des Spiels im „Northern Undead Asylum“ eingesperrt ist und zunächst eine eher erbarmungswürdige Figur abgibt.

Das soll fürs Erste genügen. ${ }^{20}$ Wenden wir uns nun der Frage zu, welche Art von Spiel DARK SOULS ist. Für gewöhnlich wird es der Kategorie des Action role-playing game (Action-RPG) zugeordnet, was ungefähr meint, dass der Spieler den Avatar in Echtzeit durch eine umfangreiche, komplex ausgearbeitete und meistens fantastisch geprägte Spielwelt steuert, deren Geheimnisse er ergründet, während er sich zahlloser Gegner zu erwehren hat. Genauer gesagt, nimmt der Spieler in DARK SOULS die sogenannte Third-Person- oder VerfolgerPerspektive ein (die Kamera ist also hinter dem Avatar positioniert, blickt ihm gleichsam über die Schulter) und hat im Prinzip eine große Freiheit, was die Frage betrifft, in welcher Reihenfolge und auf welchen Wegen er sich die Räume des Spiels erschließt; ${ }^{21}$ die Zuordnung $\mathrm{zu}$ den Rollenspielen rührt in

20 Später werde ich auf die Frage zurückkommen, wie die Geschichte von DARK SOULS, oder um genau zu sein: der von Miyazaki gewählte Modus des Erzählens, andere Aspekte des Spieldesigns aufgreift und zu welchem Zweck das geschieht.

21 Bei Tom van Nuenen etwa heißt es: „DARK SOULS is a third-person and open world action role playing game [sic] (RPG) in which the player roams the world of Lordran, encountering all sorts of demons and other antagonists. “ Tom van Nuenen: Playing the Panopticon. Procedural Surveillance in DARK SOULS. In: Games and Culture 11 (2016), H. 5, S. 510-527, hier: S. 511. Faktisch handelt es sich eher um die Suggestion einer offenen Welt, insofern die Reihenfolge, in welcher der Spieler die Gebiete erkundet, $u$. a. durch die Abstufung des Schwierigkeitsgrades und verschlossene Türen und Tore gesteuert wird. Andererseits können sich erfahrene Spielerinnen und Spieler weitgehend über derartige Lenkungsversuche hinwegsetzen. In ihrer Diskussion der Frage, ob DARK SOULS I als Open-World-Spiel betrachtet werden kann, kommen Michael Hebel, Guido Kühn und Sebastian de Andrade zu einem ähnlichen Schluss: „Die Spielwelt fühlt sich in Teilen als Open World an, ohne jedoch eine echte Open World zu sein. Interaktionsmöglichkeiten sind vom Designer bzw. der Designerin strikt vorgeben, wobei Game Breakers ein gefühltes Sandbox-Erlebnis erfahren lassen. Der/Die SpielerIn hat begrenzte Freiheiten in der Progression, obwohl die Kombination der gefühlten Open World mit dem gefühlten Sandbox-Aspekt zu einer gefühlten Free Roaming-Welt führt.“ Vgl. Michael Hebel/ Guido Kühn/Sebastian de Andrade: Who said Open World? Auswirkungen von Game-Taxonomien 
diesem Fall - ebenso wie bei anderen Action-RPGs - daher, dass dem Spieler vielfältige Möglichkeiten offenstehen, die äußere Erscheinung des Avatars zu gestalten und vor allem die Entwicklung seiner Fähigkeiten, der Stärken und Schwächen, zu bestimmen und in Hinblick auf den gewünschten Spielstil auszurichten.

Nun sind Genre-Taxonomien eine leidige Angelegenheit. Auch wenn man sie von einem Medium auf ein anderes, im gegebenen Zusammenhang also vom Film aufs Videospiel überträgt, ändert das nichts an der Tatsache, dass sie eher zur Verunklarung als zu einem vertieften Verständnis ihres Gegenstands beitragen und immer neue Aporien hervorbringen, denen sie aus eigener Kraft nicht entraten können. ${ }^{22}$ Dessen ungeachtet will ich die Zuordnung von DARK SOULS zu den Action-RPGs nicht hinterfragen, sondern vielmehr an ihr festhalten, da sie es erlaubt, die grundlegenden Mechaniken des Spiels deskriptiv zu erfassen und in ihrer ästhetischen Valenz zu bestimmen.

DARK SOULS ist demnach ein Spiel, bei dem man im Wesentlichen damit beschäftigt ist, a.) zu kämpfen, b.) zu erkunden und c.) nachzudenken. Darin unterscheidet es sich nicht von Dutzenden anderer Action-RPGs. Woraus folgt, dass die Besonderheit von DARK SOULS in der konkreten Ausgestaltung der genannten Aktivitäten, die in der Praxis natürlich nicht säuberlich voneinander getrennt werden können, zu verorten ist. ${ }^{23}$ Worin aber besteht diese Besonderheit? Anders ausgedrückt: Wenn es angemessen sein sollte, bezogen auf Hidetaka Miyazakis Spiel die Wörtchen rätselhaft und Faszinosum zu verwenden - was hat es mit der Faszination auf sich und warum ist sie rätselhaft?

Am Anfang eines Essays, in dem er DARK SOULS mit Foucaults Theorie des Panoptismus in Verbindung bringt, schreibt Tom van Nuenen:

After sinking about fifty hours in DARK SOULS [...] and beating its final boss, I put down the controller. It was clear that this game was remarkable from a technical and aesthetical perspective. Still, I felt disturbed: How did it persuade me to pour all that time into an experience that might be best summed up as near continuous agony? ${ }^{24}$

auf die SpielerInnen-Erwartungen am Fallbeispiel DARK SOULS. In: Rudolf Thomas Inderst/Pascal Wagner/Christof Zurschmitten (Hg.): Prepare to die! DEMON SOULS, DARK SOULS und BLOODBORNE. Glückstadt 2019, S. 49-70, hier: S. 66.

22 Vgl. Beil, Benjamin: Genrekonzepte des Computerspiels. In: GamesCoop: Theorien des Computerspiels zur Einführung. Hamburg 2012, S. 13-37, v. a. S. 20-30. Für eine umfassende und aus meiner Sicht kaum widerlegbare - Kritik der Genretaxonomien vgl. Hermann Kappelhoff: Genre und Gemeinsinn, S. 85-97; vgl. zu der Problematik der taxonomischen Genretheorie auch die ersten beiden Kapitel der vorliegenden Studie.

23 Die ersten beiden dieser Aktivitäten scheinen selbsterklärend; was es mit dem „Nachdenken" auf sich hat, wird noch genauer zu bestimmen sein.

24 van Nuenen: Playing the Panopticon, S. 510-511. 
Dass van Nuenen seine Zeit mit DARK SOULS als „near continuous agony“ erlebt hat, hängt, wie er im Anschluss an die zitierte Passage erklärt, unter anderem mit der „excessive difficulty“ von Miyazakis Kreation zusammen. ${ }^{25}$ Tatsächlich dürfte die Frage, die sich van Nuenen stellt, den meisten DARK-SOULS-Spielern wohlvertraut sein; sie speist sich aus dem Umstand, dass jemand seine sogenannte Freizeit, ganz ohne äußeren Zwang, auf eine Tätigkeit verwendet, die ihn einem Regime strenger Mühsal unterwirft.

Auch Keza MacDonalds lässt keinen Zweifel daran aufkommen, dass DARK souls durchaus eine Zumutung darstellt: „Ask players for their recollections“ so ihr lapidares Resümee - ,and they will tell you the moments that made them cry, the moments when they felt physically and mentally broken by a boss fight, the moments when they nearly gave up. “26 Gleichzeitig betont MacDonald aber, dass sie den Schwierigkeitsgrad von DARK SOULS, zumindest isoliert be-

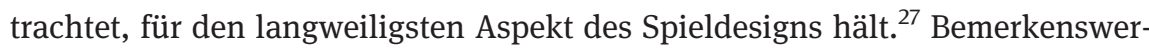
terweise teilt nahezu jeder Spielejournalist, dem es darum $\mathrm{zu}$ tun ist, die künstlerische Güte von Hidetaka Miyazakis Kreation zu preisen, dieses Anliegen: zu verhüten, dass DARK SOULS auf den Schwierigkeitsgrad reduziert wird. Chris Dahlen etwa versucht, das Peinsame eines DARK-SOULS-Durchgangs in einen größeren ästhetischen Zusammenhang einzuordnen. Er drückt das so aus: „In DARK SOULS, the difficulty isn't a club the designers bash you with, but the palette with which they paint the experience. “28

Und tatsächlich: Es würde wohl keinem Literaturkritiker, keiner Literaturwissenschaftlerin einfallen, in einer Diskussion von, zum Beispiel, William Faulkners Roman Absalom, Absalom! (1936) das Augenmerk vorwiegend darauf zu richten, wie anstrengend es sei, sich durch diese endlos langen, unter Adjektivkaskaden ächzenden Schachtelsätze zu quälen; ebenso wenig wie jemand, der sich etwas auf seine Cinephilie zugute hält, Béla Tarrs SÁTÁNTANGó (HU/D/ CH 1994) mit dem Hinweis abtun würde, die hypnotische Langsamkeit des Schnittrhythmus habe ihn bereits nach den ersten zwei Stunden in den Schlaf gewiegt. Vielmehr wäre man in beiden Fällen um ein Verständnis bemüht, was dieses oder jenes Gestaltungsmerkmal zur Gesamtheit eines ästhetischen Weltentwurfs, der Konstruktion einer bestimmten Leser- oder Zuschauerposition

25 Vgl. van Nuenen: Playing the Panopticon, S. 511.

26 Keza MacDonald: Tough Love. On DARK SOULS’ Difficulty. In: dies./Killingsworth (Hg.): You Died, S. 186-193, hier: S. 186.

27 Vgl. MacDonald: Tough Love, S. 186.

28 Chris Dahlen: What DARK SOULS Is Really All About. In: kotaku.com, 01. Juni 2018 [09. Januar 2012], https://kotaku.com/what-dark-souls-is-really-all-about-5874599 [letzter Zugriff: 12.05.2020]. 
beiträgt. In Hinblick auf Absalom, Absalom! könnte man beispielsweise sagen, der hyperkomplexe Satzbau lasse die Leserinnen und Leser die ganze Schwere einer fluchhaften, von den Gespenstern des Bürgerkriegs und der Sklaverei heimgesuchten Vergangenheit am eigenen Leib spüren; einer Vergangenheit, die einfach nicht enden will und, sinnlich greifbar in der niederdrückenden, brennendschwülen Sommerhitze, die Südstaaten unter sich zu begraben droht. In dieser Perspektive zielt Faulkners Roman darauf, eine bestimmte geschichtsphilosophische Idee nicht - oder nicht nur - diskursiv zu verhandeln, sondern sie zuvörderst in eine ästhetische Erfahrung für die Leserinnen und Leser zu transformieren.

Was übrigens schon am ersten Satz von Absalom, Absalom! deutlich wird:

From a little after two oclock until almost sundown of the long still hot weary dead September afternoon they sat in what Miss Coldfield still called the office because her father had called it that - a dim hot airless room with the blinds all closed and fastened for forty-three summers because when she was a girl someone had believed that light and moving air carried heat and that dark was always cooler, and which (as the sun shone fuller and fuller on that side of the house) became latticed with yellow slashes full of dust motes which Quentin thought of as being flacks of the dead old dried paint itself blown inward from the scaling blinds as wind might have blown them. ${ }^{29}$

Bezogen auf DARK SOULS folgt aus diesen Überlegungen, dass die entscheidende Frage lautet, was der Schwierigkeitsgrad zur Spielerfahrung beiträgt - abgesehen davon, dass es eben schwer ist, den Infamitäten der Designer standzuhalten. Ganz allgemein liegt die Vermutung nahe, dass die Faszination von DARK SOULS nicht trotz, sondern wegen des Schwierigkeitsgrads besteht; dass die Mühsal, der sich die Spielerinnen und Spieler von DARK SOULS ausgesetzt sehen, also letztlich eine lustvolle ist.

Jason Killingsworth bestätigt diese Vermutung:

The first time you slay a DARK SOULS boss, the surge of adrenaline almost blurs your vision. You scream impulsively, sending nearby pets scampering from the room. You gesture obscenely at the television. You pull up Twitter on your phone to broadcast the news to friends and strangers. You set down the controller and stare at the screen for a minute, drawing out the moment, relishing what you've just accomplished. However, the second or third time you return to a boss and find him or her a relative pushover, the outcome doesn't send nearly the same level of voltage through your limbic system.

Like a long-married person trying to spice up an overly familiar bedroom, many DARK SOULS players have experimented with creative ways of altering their approach to the game to render the experience tantalisingly alien once more. ${ }^{30}$

29 William Faulkner: Absalom, Absalom! [1936]. New York/Toronto 1986, S. 3.

30 Jason Killingsworth: Suffer Club. All Hail the Challenge Runners. In: MacDonald/Killingsworth (Hg.): You Died, S. 243-256, hier: S. 243. 
Aus Killingsworths Beschreibung lässt sich schlussfolgern, dass DARK SOULS einen Genuss verschafft, der insofern paradox ist, als er untrennbar verbunden scheint mit der „agony“, die für van Nuenen ganz wesentlich die Spielerfahrung prägt. Das ist keineswegs selbstverständlich, weil die Erbarmungslosigkeit des Spiels ja auch schlichtweg für Enttäuschung und Frustration sorgen könnte - wie es bei Survival-Horrorspielen in der Art von OUTLAST (Red Barrels, 2013) oder ALIEN: ISOLATION (Creative Assembly, 2014) mitunter der Fall ist. ${ }^{31}$ Hingegen zielt DARK Souls offenbar darauf, eine Korrelation zwischen den Intensitäten von Qual und Genuss zu erzeugen. ${ }^{32}$ Eine erste Antwort auf die obige Frage lautet also: Der peinigende Schwierigkeitsgrad des Spiels dient dazu, eine beglückende Spielerfahrung zu ermöglichen. Daraus ergibt sich freilich eine weiterführende Frage: Auf welche Weise gelingt es DARK SOULS, jenes Entsprechungsverhältnis zwischen Qual und Jubel herzustellen? Hierin besteht, so meine ich, das Rätsel, vor welches uns Hidetaka Miyazakis Spieldesign stellt.

Einen Hinweis auf die mögliche Lösung dieses Rätsels gibt Killingsworth, wenn er in einem anderen Zusammenhang erläutert, was es mit den „creative ways“ auf sich hat, die gewisse Spielerinnen und Spieler beschreiten, um die ästhetische Erfahrung von DARK SOULS immer wieder jenem Anfangsleid, jener Anfangslust anzugleichen:

Spend a few minutes browsing the Internet and you'll find videos of players who've com-
pleted From Software's dark-fantasy opus using toy guitar peripherals instead of traditio-
nal gamepads. There are speedrunners who can rip through the entire game in just 45
minutes, boasting the velocity and pathfinding ease of a skydiver. [...] a person has just
completed an entire game of DARK souls without taking a single hit, to a shield or other-
wise - a new first, which required five hours of spoon-bending levels of concentration.
There are so-called OneBros [...] who complete the game at Soul Level 1, refusing
the consolation of the bonus stats that come with levelling up your character. There are

31 Wenigstens sind diese Kritikpunkte in einschlägigen Test der beiden Spiele öfters genannt worden. Vgl. etwa: Dominik Hammes: Survival-Horror mit Camcorder. In: www.gameswelt.de, 11. September 2013, https://www.gameswelt.de/outlast/test/survival-horror-mit-camcor der,205784 [letzter Zugriff: 12.05.2020]; oder: Michael Krosta: Vom Jäger zum Gejagten. In: www.4players.de, 13. Oktober 2014, https://www.4players.de/4players.php/dispbericht/Allge mein/Test/35354/80741/0/Alien_Isolation.html [letzter Zugriff: 12.05.2020].

$32 \mathrm{Zu}$ einem ähnlichen Ergebnis kommen die Autoren einer Studie, die auf der Auswertung von an DARK-SOULS-III-Spieler gerichteten Online-Fragebögen basiert. Sie schreiben: „Players' reports indicate that high challenges and avatar death make moments of achievement meaningful and thus, enable positive player experiences." Serge Petralito/Florian Brühlmann/ Glena Iten/Elisa D. Mekler/Klaus Opwis: A Good Reason to Die. How Avatar Death and High Challenges Enable Positive Experiences. Paper zu der Konferenz „Difficulty and Challenge in Games“, CHI 2017, 6.-7. Mai 2017, Denver/Colorado, USA. 
players who complete the journey without a shield, others without any armours or weapons at all, just knuckles. ${ }^{33}$

Was lernen wir aus diesen Ausführungen? Zunächst einmal: Die ,kreativen Wege, die Herangehensweise an das Spiel zu verändern' laufen für eine unbestimmt große Zahl von Spielerinnen und Spielern darauf hinaus, die beträchtlichen Herausforderungen eines gewöhnlichen DARK-SOULs-Durchgangs immer noch weiter zu steigern, indem sie bewusst auf manches, vieles oder alles verzichten, was ihnen das Leben leichter machen könnte. Wie groß mag die Zahl dieser Spieler wohl sein? Haben wir es mit einigen Hundertausenden, gar Millionen, oder „nur“ mit ein paar Zehntausend zu tun? Letztlich ist das unwichtig. Bedeutsam scheint mir vielmehr, dass es überhaupt möglich ist, eine solche Haltung gegenüber DARK SOULS einzunehmen; dass das Spiel dergleichen erlaubt. Denn wenn sich ein ohnedies sehr schweres Spiel in einer progressiven Kurve so modifizieren lässt, dass es stetig schwerer, niemals aber unmöglich zu meistern ist, bedeutet dies, dass es über außerordentlich präzise und sorgfältig abgestimmte Mechaniken verfügen muss.

Im Fall von DARK SOULS betrifft das vor allem das Kampfsystem. Wenden wir uns also zunächst diesem offensichtlich zentralen Aspekt des Spieldesigns zu.

\section{Das gebieterische „Jetzt!“}

Im Umfeld des Spielejournalismus finden sich längst Dutzende Tests und Essays, die zu ergründen suchen, was die Kämpfe in DARK SOULS - das Herzstück der Spielerfahrung - so überaus intensiv macht. Wichtig ist sicherlich, dass Miyazaki und seine Mitarbeiter eine Mechanik entwickelt haben, die eine überschaubare Anzahl von leicht erlernbaren Angriffs-, Verteidigungs- und Ausweichbewegungen zu einer Kombinatorik erstaunlich vielfältiger, ja nahezu unerschöpflicher taktischer Möglichkeiten entfaltet. Es ist eine Kombinatorik, die zu erproben eine Fülle an situativen Entscheidungen verlangt, deren Folgen meist unmittelbar spürbar sind: Welche Waffe wähle ich? Kämpfe ich ein- oder zweihändig? Führe ich in der linken Hand eine zweite Waffe oder eine Fernwaffe, einen Schild oder eines der Utensilien, die mir erlauben, Magie, Pyromantie oder Wunder zu wirken? Ist gegen diesen Gegnertyp und unter den gegebenen räumlichen Bedingungen (etwa ein enger Gang oder ein offener Hof) eine Stich- oder eine Hiebwaffe besonders wirksam? - immer

33 Keza MacDonald/Jason Killingsworth: Prologue. Going Dark. In: dies. (Hg.): You Died, S. 1-10, hier: S. 7. 
wieder stellen sich diese und ähnliche Fragen. Sie betreffen nicht nur die Wahl der Waffen; ebenso gilt es zu entscheiden, mit welchem von Dutzenden Rüstungssets, die man im Lauf eines Spieldurchgangs finden kann (und deren Einzelteile sich wiederum nach Belieben kombinieren lassen) der Avatar ausgestattet werden soll. Auch die verschiedenen Rüstungen haben ihre Stärken und Schwächen; die eine schützt besonders gut gegen Schläge, die andere gegen Gift oder Feuer. All diese Entscheidungen werden dadurch kompliziert, dass das Gewicht der einzelnen Waffen und Rüstungen je nach der Tragkraft des Avatars beträchtliche Auswirkungen auf dessen Ausdauer und Schnelligkeit haben kann. Mit dem Ergebnis, dass die Vorteile, die sich etwa aus einem schweren Stahlpanzer und einer gewaltigen Axt ergeben, durch die Behäbigkeit, die sie bei einer physisch schwachen Spielfigur hervorrufen, zunichte gemacht werden können: Im Gerangel mit einer zahlenmäßigen Übermacht hilft die mächtigste Waffe wenig, wenn man sie nur ein paar Mal zu schwingen vermag, ehe man erschöpft innehalten muss.

Spätestens an diesem Punkt wird deutlich, wie sich das taktische Kampfsystem von DARK SOULS mit der strategischen Ausrichtung des Avatars verbindet. Zwischen den eher polaren Typen, die eindeutig auf Kraft oder Geschicklichkeit, Nahkampf oder Magie setzen, eröffnet sich auch hier eine Fülle an Kombinationen. Dabei fällt die Entwicklung der Ausrüstung ebenfalls in den Bereich der Spielstrategie, denn zur Verstärkung einer Waffe, eines Schildes oder eines Brustpanzers werden bestimmte Materialien benötigt, die umso seltener und teurer werden, je höherstufiger die entsprechende Waffe bereits ist. Das gilt für reguläre Steigerungen; es gilt umso mehr, wenn etwa ein Schwert solcherart transformiert werden soll, dass es fortan einen speziellen Schadenstypus verursacht (etwa Feuer- oder Blitzschaden), der gewissen Gegnern besonders zusetzt. Wobei viele Waffensteigerungen nur von bestimmten Schmieden durchgeführt werden können, die sich mitunter - in DARK SOULS I betrifft das vor allem den Skelettschmied Vamos - in entlegenen Winkeln der Spielwelt verborgen halten und obendrein bestimmte „Ember“ benötigen (also verschiedene Arten von „Glut“, die ebenfalls in der Spielwelt versteckt sind), ehe sie ihre Arbeit aufnehmen können.

Eine wirklich umfassende Darstellung des Kampfsystems von DARK SOULS würde noch weit mehr Raum beanspruchen. ${ }^{34}$ Dennoch mag die Funktions-

\footnotetext{
34 Es sei en passant erwähnt, dass die hier beschriebenen Mechaniken nicht nur in DARK souls zur Anwendung kommen und - obgleich From Software zweifellos für grundlegende Innovationen verantwortlich zeichnet - auch nicht unbedingt von Miyazaki und seinen Mitarbeitern erfunden wurden. Was das Kampfsystem von DARK souls einmalig macht, ist vor allem, wie eine Vielzahl von Designentscheidungen mit verblüffender Komplexität und Präzision ineinandergreifen.
} 
weise wesentlicher Mechaniken deutlich geworden sein - eine unabdingbare Voraussetzung, um das Kampfsystem des Spiels in einer erfahrungsästhetischen Perspektive auszudeuten. Denn darum dreht es sich ja: Woran sollte sich das Ingenium von Spielmechaniken bemessen, wenn nicht an den Erfahrungsqualitäten, die sie ermöglichen? Folgt man Matthias Grimm, ist diesbezüglich ein Aspekt des Kampfsystems von DARK SOULS von besonderer Wichtigkeit, der bereits in meiner Beschreibung der Spielmechaniken hervorgehoben wurde: die Notwendigkeit, in jedem Augenblick folgenreiche Entscheidungen zu treffen.

Grimm schreibt:

[D]as ist es, worum es in DARK SOULS eigentlich geht: Bedeutung. Dieser Welt eine Bedeutung abzutrotzen, und euren Taten und Entscheidungen eine Bedeutung zu verleihen. Und das in jeder einzelnen Sekunde.

DARK SOULS verlangt in jeder einzelnen Sekunde eine Entscheidung von dir, die das Spiel beeinflussen wird. [...] Es stellt dich und deine Persönlichkeit auf die Probe. Es will dich verführen, verlocken, gierig und nachlässig machen. Greife ich an? Oder gehe ich auf Nummer sicher, weiche aus, hebe den Schild, versuche mich zu regenerieren? Egal, welche Entscheidung ihr trefft, das Spiel sagt euch sofort, ob sie falsch oder richtig war. War sie richtig, werdet ihr belohnt, war sie falsch, werdet ihr bestraft, und das wird wehtun. Nur dafür gibt es den Schwierigkeitsgrad von DARK SOULS. DARK SOULS ist nicht wirklich schwer, es lässt euch lediglich die Konsequenzen eurer Fehler spüren. Es steht euch nicht bloß im Weg herum, es schlägt auch mal zurück. Denn anders ist es nicht möglich $\mathrm{zu}$ lernen, sich anzupassen und zu verbessern.

Denn darum geht es in DARK SOULS: beobachten, lernen, anpassen. DARK SOULS ist ein durch und durch asymmetrisches Spiel - es lebt von dem Ungleichgewicht zwischen Spiel und Spieler. Das Spiel ist immer größer und stärker als ich. Doch es ist fair und trägt sein Herz auf der Zunge: Es zeigt mir immer ganz genau, was es macht. Und es passt sich eben nicht an, es geht immer gleich vor. Das wiederum ist mein Vorteil als Spieler: Im Gegensatz zum Spiel bin ich in der Lage, mich anzupassen, meine Vorgehensweise zu ändern, meine Taktik zu ändern, meine Ausrüstung zu ändern. Ich beobachte, was es macht, probiere aus, mache Fehler, werde bestraft, lerne dazu, passe mich an. Bis ich gut genug bin, es zu schlagen. DARK SOULS ist kein Spiel wie SUPER MEAT BOY, in dem ich im richtigen Augenblick die richtige Taste drücken muss, sondern eines, in dem ich im richtigen Augenblick die richtige Entscheidung treffen muss - und die kann je nach Spieler, Spielstil und Situation völlig unterschiedlich sein. ${ }^{35}$

An Grimms Analyse ist - sieht man von einer gewissen Feierlichkeit ab, die DARK SOULS ein Potenzial zur ethischen Veredlung der Spieler zuschreibt - vor allem auffällig, dass es immer wieder um die Gestaltung und Erfahrung präzise

35 Matthias Grimm: Auch du liebst DARK SOULS ... ... du weißt es nur noch nicht. In: www.euro gamer.de, 18. März 2016, https://www.eurogamer.de/articles/2016-03-18-auch-du-liebst-darksouls [letzter Zugriff: 12.05.2020]. 
bestimmbarer Zeitlichkeiten geht: „In jeder einzelnen Sekunde“ müssen wir Entscheidungen treffen, die das Spiel „sofort“ belohnt oder bestraft, womit es uns zu einer Vergegenwärtigung der eigenen Fehler hinleitet, die wir dann, im Nach und Nach der Trias von „beobachten, lernen, anpassen“, korrigieren können; was wiederum möglich ist, weil DARK SOULS zwar „immer“ stärker ist als wir, sein Vorgehen dabei jedoch „immer“ transparent macht und sich vor allem „immer“ gleich verhält.

In dieser Perspektive könnte man wohl sagen - und genau besehen tut Grimm das ja auch -, der Schwierigkeitsgrad von DARK souls diene dazu, eine Vielfalt an zeitlichen Qualitäten jeweils in der Konkretion eines gebieterischen ,Jetzt!“ erfahrbar zu machen. Das Ineinander von Qual und Genuss, das die Spielerfahrung prägt, rührte dann her von der Intensität des Selbsterlebens in der Abfolge dieser dynamischen Zeitlichkeiten, die letztlich allesamt zu einer insistierenden Gegenwärtigkeit sich verdichten, die den Spieler sozusagen mit Leib und Seele in sich hineinzieht; was eben nur möglich ist, weil jede noch so kleine Fehlentscheidung das sofortige Ableben des Avatars herbeiführen kann: etwa ein Schlag zu viel oder im falschen Moment, der den Ausdauerbalken erschöpft, sodass die eigene Spielfigur wehrlos den Attackeserien ihrer Gegner ausgeliefert ist.

Eine der Wirkungen dieser Zeit-Gestaltung ist nun merkwürdigerweise, dass DARK SOULS, großes Beharrungsvermögen aufseiten der Spielerinnen und Spieler vorausgesetzt, über die Dauer vieler Stunden im „Immer gleich“ absoluter Berechenbarkeit nach und nach seinen Schrecken verliert. Es mag tatsächlich so weit kommen, dass dieses Spiel, welches sich zunächst als Hort infamer Garstigkeiten präsentiert hat, irgendwann eine Anmutung von Kuscheligkeit gewinnt. Das Spielgefühl wandle sich langsam „from bloodbath to bubble bath“, wie Jason Killingsworth es ausdrückt. ${ }^{36}$

Freilich kann man davon ausgehen, dass bei weitem nicht jeder Spieler diesen kuriosen Zustand erreicht, in dem das Unheimliche heimelig wird - die graduelle Annäherung an ihn gehört allerdings zu den grundlegenden Erfahrungen im Umgang mit DARK SOULS; sie realisiert sich, folgt man Keza MacDonald, ebenfalls als eine spezifische Zeitlichkeit:

Most DARK SOULS players can name the moment that they broke through ,the wall': you need one big, hard-won victory to cement the cycle of effort, frustration, reward and release that drives people through the game. That first big victory, where you've faced something that seemed impossible at first and conquered it after hours of failure and death

36 MacDonald/Killingsworth: Prologue, S. 10. 
and learning is also necessary before you come to understand the core idea at the heart of DARK SOULS' design: death as education. ${ }^{37}$

Was es braucht, um in DARK SOULS zu bestehen, ist also der Durchlauf unzähliger Zyklen, immer gleich, immer variiert, in denen das Voranschreiten auf den Wegen von „effort, frustration, reward and release“ und „beobachten, lernen, anpassen" mit dem dutzend-, ja hundertfachen Tod des Avatars erkauft wird. Irgendwann weiß man dann, wie sich der Skelettkrieger, der riesenhafte Feuerdämon, die glubschäugigen, Fluchnebel speienden Basilisken verhalten weiß, was sie tun werden, noch bevor sie es tun. Dann gibt es keine Überraschungen, kein jähes Erschrecken mehr; sondern nur noch die Frage, ob der Spieler in der Lage ist, sich dem eigenen Wissen gemäß zu verhalten. ${ }^{38}$

Ehe ich versuche, die vielen Zeitlichkeiten, die DARK SOULS erfahrbar macht, weiter zu ergründen - um mithin zu verstehen, warum sich zahllose Spielerinnen und Spieler begierig den Regeln jener Lehrstätte des digitalen Todes unterwerfen -, möchte ich untersuchen, ob sich vergleichbare Gestaltungsmuster auch für die anderen Hauptaktivitäten aufweisen lassen, die das Genre des Action-RPG bestimmen: In Rede stehen also das Erkunden und Nachdenken.

\section{Immer schon tot, doch nie gestorben}

Was für eine Welt ist es, die man in DARK sOULS durchstreift? Eingangs habe ich einige der Örtlichkeiten aufgezählt, aus denen sie sich zusammensetzt. Es handelt sich um Orte, die umstandslos zwei Traditionen der westlichen Populärkultur zugeordnet werden können: der Fantasy und dem Gothic-Horror. Tatsächlich sind sie so sehr eingewoben in die Motivik, die Symbolik und die Affektpoetiken der genannten Traditionen, dass man sie sich kaum losgelöst von ihnen denken kann: die verfallene Burg, die entweihte Kathedrale, der uralte Friedhof, die verfluchten Grüfte und Katakomben, der düstere Wald, das schroffe Gebirge; der Sumpf, von stinkender Pestilenz durchwabert, aus dem kein Weg zu führen scheint; die Höhle, labyrinthisch-verworren, die sich in unergründliche Tiefen windet; das Laboratorium und die Bibliothek: Stätten verbotenen Wissens, auf immer

37 MacDonald: Tough Love, S. 187.

38 Maximilian Haffelder und Patrick Maisenhölder erläutern, dass Spielerinnen und Spieler, die sich zu DARK SOULS hingezogen fühlen, in der Regel eine große Bereitschaft und Fähigkeit zum (erfolgsmotivierten) Lernen aufweisen. Vgl. Maximilian Haffelder/Patrick Maisenhölder: Digitale Selbstgeißlung? Oder: Warum SpielerInnen souls-like Spiele spielen. In: Rudolf Thomas Inderst/Pascal Wagner/Christof Zurschmitten (Hg.): Prepare to die! DEMON SOULS, DARK SOULS und BLOODBORNE. Glückstadt 2019, S. 33-47. 
gezeichnet von den unseligen Experimenten, die in ihnen vollzogen wurden; der Kerker und das Verlies: auch sie auf immer gezeichnet von dem Schmerz und dem Grauen, die sie gesehen und die sich in den verrottenden Stein ihrer Wände eingeschrieben haben ...

All diese Raumbilder stehen im Zeichen des Erhabenen, gleichviel, ob sie in Fantasy-Romanen, Horrorfilmen oder eben in DARK SOULS zur Anwendung kommen. Das Erhabene will die Nichtigkeit des Menschen erfahrbar machen, seine Ohnmacht in Anbetracht von Gewalten, die das Maß seines Denkens und Fühlens auf die Unendlichkeit hin überschreiten; zugleich zielt es darauf - zumindest so, wie es im Umfeld des Deutschen Idealismus, etwa von Kant und Schiller gedacht wurde -, das menschliche Aufbegehren gegen die eigene Nichtigkeit und Ohnmacht wenn nicht zu zelebrieren, so doch als Seins- und Handelsoption zu setzen. ${ }^{39}$

Vor diesem Hintergrund scheint die, ebenfalls zu Beginn erwähnte, Einschätzung von Gareth Damian Martin, derzufolge sich die Welt von DARK SOULS gänzlich dem Tod unterworfen sieht, durchaus stimmig: ist der Tod doch die letzte, größte und furchtbarste dieser Gewalten. Indessen erhält in DARK SOULS noch der Tod eine paradoxe Gestalt, worauf Damian Martin hinweist, wenn er „the central architectural image of the series“ beschreibt; bei selbigem handle es sich um „a crumbling edifice in which the deathless wander, meaning sapped by time from both the undead's decaying bodies and the stones that encase them". ${ }^{40}$ Was das bedeutet, führt er an anderer Stelle aus: „The spaces of the DARK SOULS series are eternally caught in a state of undeath, between collapse and continuance. Every architectural space in the series seems to oscillate between the state of tomb and room. “41

39 Als allgemeine Definition des Erhabenen schlägt Philip Shaw vor: „[W]henever experience slips out of conventional understanding, whenever the power of an object or event is such that words fail and points of comparison disappear, then we resort to the feeling of the sublime. As such, the sublime marks the limits of reason and expression together with a sense of what might lie beyond these limits.“ Philip Shaw: The Sublime. New York 2006, S. 2. Über die kantsche Konzeption des Dynamisch-Erhabenen schreibt er etwa: „It is our ability to appreciate our weakness in the face of nature and at the same time to put this weakness into perspective that transfers the attribute of ,mightiness' away from the object and towards something within the mind of the perceiver. Nature thus conceived has ,no dominion over us'. The sight of the ,boundless ocean' may dwarf my imagination, yet my ability to conceive of this deficiency points to the existence of a higher faculty, something greater than either nature or imagination." Shaw: The Sublime, S. 82.

40 Damian Martin: An obituary for the architecture of DARK SOULS’ eternally dying land. 41 Damian Martin: An obituary for the architecture of DARK SOULS' eternally dying land. 


\section{Und weiter:}

Like the series' ,hollows', a profoundly architectural name for the undead, the architecture of the DARK SOULS' series is, more than a container for walking corpses, and is instead a withering, putrefying, deathless corpse in itself. Its spaces, the cathedrals, castles, caves, sewers, fortifications and forest huts of DARK SOULS and its sequels are hollow bodies, locked in processes of organic decay. ${ }^{42}$

Das heißt, der Tod ist in DARK SOULS ein zugleich tyrannischer und zaghafter Herrscher: Alles hat er angerührt, nichts jedoch zertreten unter dem Stiefel der Vergänglichkeit. „Tot“, „untot“, „todlos“ - diese Ideen und Konzepte sind in Hidetaka Miyazakis Weltentwurf radikal auf den Entwurf einer in sich konflikthaften Zeitlichkeit bezogen, die ein überaus widersinniges Konstrukt ins Werk setzt, haben wir es hier doch mit einem, wie Damian Martin sagt, ewig sterbenden Leben zu tun, das nie lebendig war, nie aber auch sein Ende erreicht. ${ }^{43}$ Diese Zeitlichkeit gemahnt an Albträume, in denen man, von etwas Grauenhaftem gehetzt, verzweifelt um sein Leben rennt, ohne einen Schritt voranzukommen. Mit diesen Vergleichen und Bildern ist keine poetisierende Interpretation angestrebt, und auch keine Evokation einer gotischen Empfindsamkeit; ${ }^{44}$ es handelt sich

42 Damian Martin: An obituary for the architecture of DARK SOULS' eternally dying land.

43 Damian Martin: An obituary for the architecture of DARK SOULS' eternally dying land. Vgl. dazu die folgende, sehr eindrückliche Beschreibung Damian Martins: „The spaces of DARK SOULS, from its cathedrals to its humble huts, are cursed to remain ruins forever. As virtual spaces, these seemingly shattered structures are in fact fashioned as ruins by From Software's exceptionally talented artists, their collapse frozen in single frames of beautiful decay. They are ultimately without a past or a future. They will never give in to entropy, erosion and time, and be erased from the landscape, and neither can they possess a true golden past, a moment when they were total, complete, unbroken. They were built as ruins and as ruins they will stay, so that in a thousand years we might return to these spaces and find them as we left them, in collapse but never collapsing, gesturing towards an end of the world that has, improbably, both arrived and yet will never come.“ Vgl. auch Andreas Meier-Inderwildi: Zwischen Ritual, Mythos und Geschichte. Zyklen der Erneuerung und des Niedergangs in DARK SOULS. In: Rudolf Thomas Inderst/Pascal Wagner/Christof Zurschmitten (Hg.): Prepare to die! DEMON SOULS, DARK SOULS und BLOODBORNE. Glückstadt 2019, S. 113125, v. a. S. 122. Für eine mehr auf Narration und Darstellungsebene bezogene Analyse der Todesgestaltung in DARK SOULS vgl. zudem: Philipp Söchtig: Die Ästhetik des Todes in SOULSBORNE. In: Rudolf Thomas Inderst/Pascal Wagner/Christof Zurschmitten (Hg.): Prepare to die! DEMON SOULS, DARK SOULS und BLOODBORNE. Glückstadt 2019, S. 197-213.

44 Wobei ich durchaus der Meinung bin, dass DARK SOULS einer gotischen Empfinsamkeit zuneigt - zumindest, wenn man diese als den Versuch definiert, das Verworfene, Depravierte und Schauerliche gerade in seiner Verworfenheit, Depraviertheit und Schauerlichkeit als genussvolle ästhetische Erfahrung zu gestalten. Ich habe versucht, in der Analyse einiger beispielhafter Filme von Mario Bava zu zeigen, was das in concreto bedeuten mag. Vgl. Daniel Illger: Träume für die Toten. Mario Bava und die Gespenster des italienischen Horrorfilms. In: Thomas Koebner (Hg.): Gespenster. München 2014, S. 150-188. 
schlicht um den Versuch, die Qualität der temporalen Abläufe, denen jede Spielerin, jeder Spieler von DARK SOULS unterworfen ist, deskriptiv zu erfassen.

Was das bedeutet, lässt sich gut an einer Mechanik beschreiben, die ich bislang nicht berücksichtigt habe: Stirbt der Avatar, geht damit der Verlust sämtlicher bis zu diesem Punkt - vor allem über das Töten von Gegnern - gesammelter Seelen einher. Da Seelen die Universalwährung des Spiels sind, die man etwa braucht, um die Werte der eigenen Figur zu steigern und seine Ausrüstung zu verbessern, werden die meisten Spieler bestrebt sein, das Verlorene zurückzuholen; außer vielleicht, sie haben bereits eine sehr hochstufige Figur oder versuchen sich an einem „Soul Level 1“-Durchgang. Man hat nun genau eine Chance, den Ort zu erreichen, wo die Spielfigur ihr Ende fand, um die zuvor erworbenen Seelen, die in Gestalt eines grünlich schimmernden, flammenartigen Waberns über dem Boden schweben, zurückzuholen. Dass etwas Derartiges möglich ist, legt nahe, dass der Tod des Avatars in DARK SOULS zwar eine Unterbrechung des zeitlichen Kontinuums anzeigt, welches mit dem Spielstart begonnen hat, nicht jedoch eine temporale Zurücksetzung bedeutet, in dem Sinne, dass etwas Getanes widerrufen würde, als wäre es niemals geschehen. Auch die Tatsache, dass man vor dem Ableben der Spielfigur gesammelte Gegenstände behält (etwa Waffen oder Rüstungsteile) und Tore, Türen und Gitter, die man einmal geöffnet hat, nicht aufs Neue unpassierbar gemacht werden (sofern damit eine Abkürzung freigeschaltet wurde), zeigt dies an.

Einerseits haben wir es also mit einem Zeitstrahl zu tun, der immer nur nach vorne weist. Andererseits jedoch werden, von den Bossen und einigen speziellen Feindtypen abgesehen, alle Gegner wiederbelebt, die man während des vorherigen Durchgangs besiegt hatte, ehe der Avatar selbst zugrundeging. Zudem wird man nach dem Ableben der Spielfigur an das Leuchtfeuer zurückversetzt, an dem man zuletzt geruht hat; die Leuchtfeuer dienen in DARK SOULS als Speicherpunkte und Zufluchtsorte - sich hier niederzulassen, ist die einzige Möglichkeit, das Spiel zu pausieren -, sind jedoch vor allem im ersten Teil der Trilogie spärlich verteilt, sodass man mitunter gezwungen ist, sehr weite (und gefahrvolle) Wege zurückzulegen, bis man zu seinen Seelen gelangt.

Das hat nun zwei Konsequenzen für das temporale Erleben der Spielerinnen und Spieler: Zum einen wird die nach vorne drängende, lineare Zeit von einer anderen Zeitlichkeit herausgefordert, die auf zyklischen Abläufen und Wiederholungen beharrt; zum anderen setzt DARK SOULS dem Bemühen, jene beiden Dimensionen des Zeitlerlebens nach dem Tod des Avatars von Neuem zu synchronisieren, allen Widerstand entgegen, den es in Gestalt seiner Gegnerhorden aufzubringen vermag. 
Die Anspannung, die damit einhergeht, jenen Punkt der Synchronizität zu erreichen, wird in aller Regel umso mehr anwachsen, je wertvoller und schwerer erreichbar das verlorene Seelengut ist; ohnedies aber verlangt die Notwendigkeit, sich immer wieder denselben zyklischen Abläufen auszusetzen - es scheinen ja in der Tat die selben, nicht nur die gleichen Gegner zu sein, die man ein ums andere Mal bezwingen muss, und allemal ändert sich nichts an den Wegen, die es zurückzulegen gilt -, verlangt diese Notwendigkeit den Spielerinnen und Spielern einige Willenskraft und Ausdauer ab. Wobei die Anspannung durchaus in einen meditativen Zustand umschlagen kann; ein Loslassen, ein passives und friedliches und irgendwann beinah entspanntes Sich-Dreinfügen in das Unvermeidliche der zehnten, zwanzigsten, mag sein fünfzigsten zyklischen Wiederholung. ${ }^{45}$

Es ist keineswegs unwichtig, dass dieser Zusammenprall konfligierender Zeitlichkeiten nicht nur auf der Mikroebene des einzelnen Zyklus von Tod und Erneuerung des Avatars sich ereignet, sondern ebenso auf der Makroebene, womit im gegebenen Zusammenhang ein vollständiger Spieldurchgang gemeint ist, zu seinem Recht kommt. Denn nachdem der letzte Gegner besiegt, ein Ende (welches auch immer) erreicht und der Abspann gelaufen ist, beginnt DARK Souls wieder von vorne. Wobei es strenggenommen gerade nicht „von vorne beginnt“, sondern die Reise des Avatars auf rätselhafte, innerdiegetisch völlig unerklärte Weise sich fortsetzt, indem sie an ihren Ausgangspunkt zurückkehrt: Der Avatar behält seine Werte, seine Seelen, den Großteil der erworbenen und gesammelten Ausrüstung und sein Wissen um das, was ihn erwartet, über viele Stunden eingepflügt ins Gedächtnis der Spielerinnen und Spieler. Und natürlich sind sämtliche Gegner, einschließlich der Bosse, wieder da. Weder an den Orten, wo sie der Spielfigur auflauern, noch an ihrer Zahl, noch an ihren Angriffs- und Verteidigungsmustern hat sich etwas geändert; nur deutlich stärker, gefährlicher und hartnäckiger sind sie geworden, seit man sich zum ersten Mal in ihr Reich verirrte.

Dieses „Spiel“, dieses Ineinander von Immer-Neu und Immer-Gleich, von unausgesetzter Wiederholung und ebenso unausgesetzter Progression, lässt sich im Prinzip bis ins Unendliche fortsetzen (wobei der Schwierigkeitsgrad nach dem siebten Durchlauf nicht mehr weiter ansteigt) und darf in Entsprechung zu jenem anderen Ineinander, dem von Qual und Genuss, betrachtet werden; mit der Einschränkung, dass nicht eindeutig bestimmt werden kann, welcher Zeitlichkeit welches Gefühl zugehört. Dass dem beschriebenen Kreislauf kein, wenn

45 Ich danke Raphael Schotten dafür, dass er mich auf dieses mögliche Umschlagen von Frustration in Meditation hingewiesen hat. 
man so sagen darf, natürliches Ende gesetzt ist, ergibt sich konsequenterweise aus dem Umstand, dass die Untoten von DARK SOULS, wie es im Prolog heißt, „the end of the world“ erwarten; ${ }^{46}$ jenes andere Ende also, das zugleich die Natur und die Zeit und das Leben in allen von Menschen denkbaren Formen verabschiedet und noch weit jenseits des (subjektiv freilich hinreichend endgültigen) Todes der Einzelwesen zu verorten ist.

Diese Zeitkonstruktion folgt einem strengen affektpoetischen Kalkül. Das wird nicht zuletzt daran deutlich, dass sich DARK SOULS II, an dessen Entwicklung Miyazaki nur als Berater beteiligt war, diesbezüglich zwei Inkonsequenzen zuschulden kommen lässt: Zum einen verschwinden die Gegner aus bereits erforschten Gebieten, wenn man sie nur oft genug besiegt hat. Auch diese Variante hat ihre Vorzüge, da so - vorausgesetzt, wir haben es mit keinem übermäßig begabten Spieler zu tun - nach und nach eine völlig verlassene, nur noch von Stille und Schweigen beherrschte Welt entstehen mag. ${ }^{47}$ Sie mindert jedoch beträchtlich den Eindruck einer zyklischen Zeitlichkeit, aus der es, was immer man tut, letztlich kein Entrinnen gibt. Zum anderen gestaltet das sogenannte „New Game Plus“ (NG+) im zweiten Teil der Trilogie keine exakte Spiegelung der Welt, die man beim ersten Durchlauf kennenlernte: Es ändern sich nämlich die Verteilung und Aufstellung der Gegner, was so weit geht, dass einige von ihnen zwischenzeitlich neue Angriffstechniken gelernt zu haben scheinen. Wiederum gilt, dass manches für die Variante spricht, welche die federführenden Entwickler von DARK SOULS II bevorzugt haben. Selbstredend erlebt man mehr Überraschungen, wenn sich das Spiel etwas Neues einfallen lässt, um seine Spielerinnen und Spieler zu plagen. Ebenso klar ist aber, dass sich die Anmutung eines endlos wiederholten Kreislaufes nicht recht einstellen will, wenn sich die Spiegelung gewissermaßen als verzerrt entpuppt. ${ }^{48}$

Was für Folgen die im ersten und dritten Teil der Trilogie prävalierende Zeitkonstruktion hinsichtlich der Erkundungstätigkeiten des Spielers hat, kann

46 Um genau zu sein, heißt es: „And in this land, the Undead are corralled and led to the north, where they are locked away, to await the end of the world ... This is your fate.“

47 Übrigens haben Stille und Schweigen allgemein einen gewichtigen Anteil an der Welterfahrung, die DARK SOULS gestaltet; hierin ähnelt die Poetik der Trilogie jener von SHADOW OF THE Colossus - bis zu dem Punkt, dass Stille und Schweigen in düsteren orchestralen Bombast umschlagen, sowie ein Bosskampf ansteht.

48 Es geht hier nicht darum, DARK SOULS II zu schmähen. Ich würde Keza MacDonald zustimmen, die schreibt: „Few would argue that co-directors Tomohiro Shibuya and Yui Tanimura made a fine, respectful work of painstaking DARK SOULS homage. [...] a slighlty worse DARK SOULS is better than $90 \%$ of other video games." Keza MacDonald: Epilogue. What FROM Did Next. In: dies./Killingsworth (Hg.): You Died, S. 275-279, hier: S. 276. 
man gut aus der Beschreibung ersehen, die Chris Dahlen über seine Erfahrungen mit „Sen’s Fortress“ gibt, eines der gefürchtetsten Gebiete des ersten DARK SOULS:

The first section of Sen's Fortress is the most challenging. It acts as a kind of overture, introducing all of the elements that will give you grief: pressure plates in the floor that trigger traps in the wall; tough, fast lizard men; snipers that shoot lightning bolts at you from the darkness; and platforming sections, that force you to thread your way across narrow catwalks between giant swinging axeblades. Fall off the catwalk and you end up in a mucky pit where your movement is restricted and demons lurk in the darkness, waiting to clock you. Get stuck there once and you'll be even more nervous the next time you run that gauntlet, which just makes executing your moves even harder.

If you're a so-so player like me, you may run through this opening section a dozen times before you're comfortable with it, and you'll still screw up every third or fourth time thereafter. ${ }^{49}$

Ganz offensichtlich wäre ein solches Leveldesign weniger furchterregend, wenn man absehen könnte, dass die Gegner, mit denen man es zu tun hat, früher oder später endgültig das Zeitliche segnen; und auch der von Jason Killingsworth als „bloodbath to bubble bath“-Effekt benannte Lernprozess würde tendenziell auf die Ebene der individuellen Spielerfahrung verschoben - wäre also nicht mehr uneingeschränkt als Element einer affektpoetischen Komposition zu rekonstruieren -, wenn die Notwendigkeit, etwa gegen die Echsen- oder Schlangenkrieger

49 Dahlen: What DARK SOULS Is Really All About. Es spricht übrigens einiges dafür, dass die Schwierigkeiten bei der Erkundung von „Sen’s Fortress“, die Dahlen beschreibt, nicht zuvörderst seinem persönlichen Vermögen oder Unvermögen als Spieler zuzuschreiben sind, sondern bis zu einem gewissen Grad als Gegebenheiten des Leveldesigns bezeichnet werden können. Man betrachte etwa die folgenden Ausführungen Tom Bramwells, die jenen von Dahlen in bemerkenswertem Maße ähneln: „I can’t remember if it was the first Serpent Soldier I encountered who pasted me all over the floor, but if it wasn't him then it was the arrow trap I didn't notice I was triggering as I panicked at the sight of him. Next time, I made it past this room onto a narrow walkway punctuated by swinging blades. I was sent flying into the gloom below either because a hidden Serpent Soldier came running at me and I lost my footing, or possibly because I was knocked back by the Mage casting lightning spells from a distant platform. I can't remember which of these fates befell me first, I should say - they both did for me at some point.

Either way, I fell into The Pit, home to four Titanite Demons. I had run into one of these guys before, in the large room next to the bonfire on the other side of the bridge just prior to Sen's Fortress. He blocked the path to Darkroot Garden and I used to run around him out of fear rather than taking him on, because he generally flattened me. Four. Now I would be avoiding these guys as well.“ Tom Bramwell: Games of the Generation: Dark Souls. Reappraise the Sun. In: www.eurogamer.net, 31. Oktober 2013, https://www.eurogamer.net/articles/2013-1031-games-of-the-generation-dark-souls [letzter Zugriff: 12.05.2020]. 
aus „Sen’s Fortress“ zu kämpfen, bis man sich ihre Bewegungsmuster in jeder Einzelheit eingeprägt hat, gemeinsam mit diesen verschwinden würde.

Dahlens Beschreibung verdeutlicht außerdem, dass man sich in DARK SOULS nicht nur gegen übermächtige Feinde zur Wehr setzen muss, die den Avatar von allen Seiten angreifen, dabei gerne mal zu hinterhältigsten Mitteln greifen, und ihm zudem mit einigen wenigen Treffern den Garaus machen können. Nein, obendrein sind es die Räume selbst, die ihn bedrohen; mit Fallen und Hindernissen (sowie Schluchten und Abgründen) gespickt, scheinen sie nur darauf zu warten, den kleinsten Fehltritt mit dem Tod zu bestrafen. Derlei Garstigkeiten sind nicht zufällig da. Sie stehen durchaus im Einklang mit dem melancholischen Zeitregime, dem die Welt von DARK SOULS unterworfen ist und das ich mithilfe der architektonischen Betrachtung Damian Martins zu erläutern suchte. Wie gesagt: Alles in diesem Spiel stirbt, ist bereits gestorben, ohne darum tot zu sein. Im selben Moment ist jedoch das Gegenteil zutreffend: Alles in DARK SOULS lebt, wird immer leben, ohne darum lebendig zu sein.

Und dieses Paradoxon betrifft nicht nur die mehr oder weniger menschenähnlichen oder ganz und gar fremdartigen Wesenheiten und Kreaturen, die den Spieler heimsuchen, sondern eben auch die Räumlichkeiten: Wände, Decken und Böden, Statuen und Standbilder, ja sogar Einrichtungsgegenstände wie Kisten (die sich mitunter in groteske Monster, „Mimics“ genannt, verwandeln, wenn man sie öffnet) haben in DARK SOULS einen Willen; einen durch und durch boshaften Willen, wie man hinzufügen muss. All das nicht-tote, nicht-lebendige Leben, das die Welt dieses Spieles beherrscht, ist nicht einfach dem Tod zugeneigt, wie es jedes Leben, das den Gesetzen von Raum und Zeit untersteht, mit Notwendigkeit sein muss. Vielmehr ist es Leben für den Tod: Es will den Tod, will seiner Herrschaft dienen, will ihm, der in DARK SOULS, seiner uneingeschränkten Macht zum Trotz, ein etwas lässliches Zepter führt, sozusagen auf die Sprünge helfen. Als könnte dieses Un-Leben es nicht ertragen, dass da etwas ist, was wahrhaft lebt, könnte auch das eigene fluchhafte Zwischendrin nicht ertragen, sodass nur noch die Sehnsucht nach dem Nichts, der Vernichtung bleibt.

Das ist meines Erachtens die einzig schlüssige Erklärung, warum sich in DARK souls nahezu die gesamte Spielwelt gegen den Avatar verschworen hat und ihn um jeden Preis zugrunderichten will. Man spielt ja selbst einen Untoten, ist, was das betrifft, also kein Fremdling in einer untoten Welt. Doch der oder die Untote, welche die Spielerinnen und Spieler verkörpern, ist, um im DARK-SOULS-Jargon zu bleiben, nicht „hollow“, nicht „ausgehöhlt“.50 Dieses Stückchen untotes Leben

50 Genau genommen, scheint es in DARK SOULS zwei Arten des „Ausgehöhlt-Seins“ zu geben. Die eine lässt sich als Spielmechanik beschreiben, als ein Zustand des Avatars, der mit bestimmten 
hat also noch nicht jede Hoffnung aufgeben. Warum das so ist, weiß man nicht; worauf man in der Welt von DARK SOULS hoffen könnte, ist ebenfalls unklar. Aber selbst eine Hoffnung, die ihren Grund und ihr Ziel in sich selbst hat, ist wohl noch Hoffnung - Hoffnung genug, um alles, was nicht mehr hofft, zu erbittern; Hoffnung genug, um eine erbarmungslose Feindschaft heraufzubeschwören.

\section{Zwischen Stasis und Dynamik}

Es ist dies ein Geheimnis, in dem sich eine ebenso abgründige wie folgerichtige Logik vollzieht. Wie die anderen Geheimnisse von DARK SOULS, lässt es sich auflesen aus den Bruchstücken einer Geschichte. Ein paar wenige dieser Geheimnisse sollen späterhin gewürdigt werden.

Wenn wir für den Moment zu der Spieleraktivität der Welterkundung und der mit ihr verbundenen Zeitlichkeit zurückkehren wollen, heißt es zunächst, einen Nachtrag vorzunehmen. Unter Rückgriff auf Dahlens Bericht über die Unbilden von „Sen’s Fortress“ lässt sich nämlich die temporale Qualität bestimmen, die jedem Versuch, in einem bislang unbekannten Gebiet der DARK-SOULS-Trilogie wortwörtlich Fuß zu fassen, ihr Gepräge gibt: Es ist ein langsames, vorsichtiges, von nie nachlassender Wachsamkeit getragenes Sich-voran-Tasten - auch eine Gegenwärtigkeit, auch ein „Jetzt!“ mit anderen Worten. Und einmal mehr gilt, dass das, was bezogen auf die Mikroebenen des einzelnen Levels oder gar des einzelnen Levelabschnitts zutrifft, eine Entsprechung auf der Makroebene findet, womit hier das Bauprinzip der Spielwelt insgesamt angesprochen ist.

Raphael Schotten arbeitet die besondere Beschaffenheit der von Miyazaki gestalteten Spielwelt in einem Vergleich mit THE wITCHER 3 heraus. Die Bauweise der Welt von letztgenanntem Spiel - und ihr Verhältnis zu den Bewegungsmöglichkeiten des Spielers - beschreibt Schotten wie folgt:

Der Spielercharakter wird in eine erhöhte Position in der virtuellen Topografie gebracht, beispielsweise durch das Besteigen eines Hügels. Von hier aus wird nun Überblick über die anschließend erfolgende Bewegung möglich: Der Operator (und innerdiegetisch, der

Nachteilen (man hat reduzierte Widerstandskraft und kann keinen anderen Spieler zur Hilfe rufen), aber auch gewissen Vorteilen (man kann von keinem anderen Spieler überfallen werden) einhergeht. Die andere beschreibt einen existenziellen Zustand der Hoffnungslosigkeit, dem der Avatar in letzter Konsequenz erst dann verfällt, wenn der Spieler den Versuch, DARK SOULS zu meistern, ein und für alle Mal aufgibt. Ich werde später ausführlich auf den von Miyazaki entwickelten Mehrspieler-Modus eingehen. 
Spielercharakter) kann das Ziel der Reise visuell wahrnehmen - in diesem Beispiel eine Stadt am Horizont. Die Richtung der notwendigen Bewegung lässt sich abschätzen, eventuell lassen sich sogar konkrete Straßen und Pfade erkennen, denen die Bewegung folgen könnte. Auch lässt sich das qualitative Erlebnispotenzial abschätzen, wenn die so vorgenommene Peilung beispielsweise erahnen lässt, dass die Bewegung durch einen Wald, einen Sumpf und vorbei an einem Lager, von dem eventuell sogar Rauch aufsteigt, führen wird. Für dieses Beispiel könnte man also annehmen, dass der Spielercharakter im Rahmen dieser Reise erwartungsgemäß im Wald vor einem Bären flüchtet, im Sumpf eine Begegnung mit einer Sumpfhexe hat und sich an der brennenden Lagerstätte einer Gruppe Banditen erwehren muss, bevor endlich die Stadt, das Ziel der Reise, erreicht ist. ${ }^{51}$

Für Schotten korrespondiert dieser Art der Weltgestaltung ein spezifischer Modus der Welterschließung, welchen er mit den Attributen „planbar, linear und naturalistisch" beschreibt. ${ }^{52}$ Dieser Modus, überaus prägend für die Fantasy und ihre mythopoetischen, aus Geschichten gemachten Welten, zielt auf einen Spielgenuss, der sich wesentlich von der Sehnsucht nach dem offenen Horizont nährt - und dem Wunsch zu erkunden, was jenseits des Horizonts sich verbergen mag -, also vorwiegend auf eine, mitunter ganz buchstäblich, horizontale Dynamik und Vektorialität hin kalkuliert ist. Ein derart umfängliches Spiel wie THE WITCHER 3 lockt dabei mit dem Versprechen, dass sich die Bewegung, die das Jenseits eines Hügels, eines Waldstücks, eines Dorfs oder einer Stadt erschließt, nahezu unbegrenzt oft wiederholen könnte. Aber laut Schotten gilt der beschriebene Modus auch für Spiele, „die keinen vollkommen (beziehungsweise größtenteils) frei navigierbaren Handlungsraum aufweisen “53 und eine virtuelle Topografie in bescheidenerem Maßstab entwerfen, etwa BALDUR's GATE (BioWare, 1998) oder PILLARS OF ETERNITY, woraus man die Vermutung ableiten könnte, der beschriebene Modus der Weltgestaltung und -erschließung zähle, was das Genre Fantasy im Videospiel betrifft, zu den prävalenten Designkonzepten. ${ }^{54}$

51 Raphael Schotten: All Lands Meet at the End of the Earth. Raum- und Zeitpoetik in der DARK SOULS-Reihe. Freie Universität Berlin 2017 (unveröffentlichte Hausarbeit), S. 18. Eine überarbeitete Fassung dieser Studie ist erschienen unter: Schotten, Raphael: All Lands meet at the End of the World. Raum- und Zeitpoetik in DARK SOULS. In: Rudolf Thomas Inderst/Pascal Wagner/Christof Zurschmitten (Hg.): Prepare to die! DEMON SOULS, DARK SOULS und BLOODBORNE. Glückstadt 2019, S. 175-196.

52 Schotten: All Lands Meet at the End of the Earth, S. 18 [Herv. i. O.].

53 Schotten: All Lands Meet at the End of the Earth, S. 18.

54 Er schließt sich der Fähigkeit und Neigung des Mediums an, die Erkundung der Spielwelt, die Ausgestaltung ihrer Zeitlichkeit und Moralität, in die Hände der Spielerinnen und Spieler zu legen; hierin begründet sich für mich das priveligierte Verhältnis zwischen Fantasy und Videospiel. Vgl. das zweite Kapitel der vorliegenden Studie. 
Wie verhält es sich nun in DARK SOULS? Von Planbarkeit, Linearität und Naturalismus kann hier keine Rede sein, wie wir sogleich sehen werden. Schotten betont zunächst, dass die einzelnen Gebiete des Spiels „einem Zustand der Hermetik zustreben“, das heißt:

Der Sumpf grenzt hier nicht in einem Grenzgebiet an den Wald, sondern Sumpf und Wald existieren für sich, und sind im Zweifelsfall nur durch einen klar definierten Übergangspunkt und nicht in einem Grenzgebiet, in dem der Waldboden langsam feuchter wird und schließlich in Sumpf übergeht, miteinander verbunden. ${ }^{55}$

Daraus lässt sich als ein erstes wesentliches Charakteristikum der Spielwelt von DARK SOULS ableiten, „dass räumlich navigierbare Verbindungen zwischen Gebieten verschiedener Repräsentationskategorien nur punktuell und nicht liminal bestehen“. ${ }^{56}$ Diese Eigenschaft ist eng mit einer zweiten, nicht minder wichtigen verbunden; jener nämlich, dass die Welt des Spiels, wie Schotten es ausdrückt, grundsätzlich ,nicht transitorisch, sondern konkret ${ }^{*}$ verfasst ist. $^{57}$ Um ein Beispiel zu geben: „Die Shaded Woods in DARK SOULS II sind nicht ein Waldgebiet, in dem es gerade oder oft nebelig ist - sie sind ein nebeliges Waldgebiet. "58 $\mathrm{Zu}$ der Stasis, in der die einzelnen Gebiete verharren, gehört desgleichen „die Abwesenheit eines emulierten Alltagslebens“. ${ }^{59}$ Das betrifft sowohl die Gegner als auch die Nichtspielercharaktere: Beide erwachen erst zum Leben, wenn die Spielfigur sich ihnen annähert, also bekämpft werden kann, oder sie anspricht, mithin als Interaktionspartner zur Verfügung steht. ${ }^{60}$

Die bislang umrissenen Charakteristika der von Hidetaka Miyazaki entworfenen Spielwelt müssen um weitere wichtige Aspekte ergänzt werden. Da ist zum einen der Umstand zu nennen, dass die Dynamik und Vektorialität der Welterschließung und -erkundung in DARK SOULS nicht horizontal, sondern vertikal verläuft. Franziska Ascher zieht diesbezüglich einen überraschenden, aber durchaus sinnigen Vergleich: Die Spielwelt sei, so schreibt sie, „wie ein Hochhaus aufgebaut: Viele überlagernde Ebenen, verwirrende Treppenschächte, Aufzüge, frei schwebende Zwischengeschosse und Plattformen“. ${ }^{61}$ Die Architekten dieses

55 Schotten: All Lands Meet at the End of the Earth, S. 19-20.

56 Schotten: All Lands Meet at the End of the Earth, S. 19.

57 Vgl. Schotten: All Lands Meet at the End of the Earth, S. 19.

58 Schotten: All Lands Meet at the End of the Earth, S. 19.

59 Schotten: All Lands Meet at the End of the Earth, S. 19.

$60 \mathrm{Vgl}$. Schotten: All Lands Meet at the End of the Earth, S. 19.

61 Franziska Ascher: Die Narration der Dinge Teil II. Environmental Storytelling. In: Paidia. Zeitschrift für Computerspielforschung, 14. November 2014, http://www.paidia.de/die-narra tion-der-dinge-teil-2/ [letzter Zugriff: 12.05.2020]. 
Hochhauses dürften freilich wenig Interesse daran gehabt haben, dass irgendjemand tatsächlich in dem von ihnen entworfenen Gebilde leben kann, denn wie Aschers Beschreibung nahelegt - und hier trifft sie sich mit dem, was etwa Dahlen von „Sen's Fortress“ berichtet - handelt es sich bei ihm um ein von zahllosen Irrwegen, Sackgassen, Klüften und Abgründen durchzogenes, mit tödlichen Fallen gespicktes Labyrinth.

Immerhin eine Hilfestellung gewährt die Welt von DARK SOULS den Spielerinnen und Spielern: Es ist nämlich so, dass man, sorgfältige Erkundung vorausgesetzt, immer wieder Abkürzungen findet, die - zumeist vermittels Türen, Toren, Leitern und Aufzügen, die man zuvor schon erspäht hat, ohne sie durchschreiten oder erklettern beziehungsweise in Betrieb nehmen zu können - auf mitunter überaus verblüffende Art, man möchte beinah von architektonischen Epiphanien sprechen, an vermeintlich weit entfernte Orte und eben zur Geborgenheit eines Leuchtfeuers zurückführen.

Wie muss man sich das vorstellen? Ascher gibt folgendes Beispiel:

Hat man beispielsweise den Taurusdämon (einen der ersten Bosse im Spiel) besiegt, tritt man durch eine kleine Seitentür in einen Torbogen. Gegenüber liegt eine weitere Türe, allerdings lässt sie sich zu diesem Zeitpunkt ohne Generalschlüssel nicht öffnen. Schafft man es nun, die Brücke zur Linken zu überqueren, ohne dem Brückenwyvern zum Opfer zu fallen, findet man am Ende der Treppe zur Rechten eine Leiter, die man zu eben jenem Leuchtfeuer, von dem aus man zuvor zum Taurusdämon aufgebrochen ist, herunterlassen kann. Vom selben Leuchtfeuer bricht man nun zum nächsten Spielabschnitt auf. Hat man den Kellerschlüssel schließlich in der Kirche der Untoten an sich gebracht, kann man die Türe, an der man zuvor tatenlos vorbeigehen musste, aufschließen und gelangt in die unteren Bereiche der Untotenstadt. Bevor man jedoch mit deren Erkundung beginnt, ist es ratsam, zunächst rechts die Treppe hinaufzusteigen und an ihrem oberen Ende eine Gittertüre zu entriegeln, die sich nur von dieser Seite öffnen lässt und wiederum eine Abkürzung zum nur zwei Brücken entfernten Ausgangsleuchtfeuer herstellt. ${ }^{62}$

Dank ihrer Genauigkeit vermitteln Aschers Ausführungen einen Eindruck von der bis zur Verworrenheit (und Verwirrung) komplexen Wegführung innerhalb der DARK-SOULS-Welt, die man auf sich allein gestellt, also ohne eine vom Spiel automatisch mitgezeichnete Karte navigieren muss (ich werde auf diesen Punkt zurückkommen); bedenkt man den erbarmungslosen Schwierigkeitsgrad und das allgemein an Unbilden reiche Leveldesign, bekommt man eine Vorstellung davon, was das Auffinden einer Abkürzung für die Spielerinnen und Spieler bedeutet: Freude, Erleichterung, Hoffnung.

62 Ascher: Die Narration der Dinge Teil II. 
Nunmehr sollte deutlich geworden sein, inwiefern die Makrostruktur der Spielwelt von DARK SOULS die Zeitlichkeiten reflektiert, die sich im Kampfsystem, der Erkundung und dem atmosphärischen Gepräge der Topografien gestaltet finden: Es gibt die Zeit des Dazwischen, die sich ausdrückt im Ineinander von TotSein und Lebendig-Sein, die zugleich die Abwesenheit von beidem meint; sie findet ihren Niederschlag in dem Spannungsverhältnis zwischen der Stasis, welche die einzelnen Gebiete des Spiels auf ewig in der erstarrten Unabänderlichkeit eines umwölkten Tages oder einer nebeligen Dämmerung sowie einer bestimmten stofflichen Beschaffenheit (etwa des sumpfigen Bodens oder des verfallenden Steins) festhält, und der erstaunlich großen Vielfalt, die augenscheinlich wird, wenn man die verschiedenen Gebiete in ihrer Gesamtheit betrachtet. Letztere sorgt dafür, dass die Welt von DARK SOULS in der Erstarrung doch auch wieder eine rätselhafte Dynamik entfaltet: Die Abfolge von verschiedenen Qualitäten des Lichts und der Materialität realisiert eine Variation der melancholischen Grundstimmung, die sich in der Spanne von zauberisch-verwunschener Schönheit („Darkroot Garden“) bis hin zu siecher Widerwärtigkeit („Blighttown“) auffaltet. ${ }^{63}$

Auf ein ganz ähnliches Spannungsverhältnis verweist die Abwesenheit emulierten Alltagslebens: Zwar deutet DARK SOULS hier und da die Möglichkeit von etwas wie Alltagsleben an (was den ersten Teil der Trilogie betrifft, gilt das vor allem für die Gebiete „Undead Burg“, „Undead Parish“ und „Anor Londo“), verzichtet jedoch darauf, diese Möglichkeit zu realisieren. Stattdessen haben wir es einmal mehr mit einer unheimlichen Erstarrung zu tun, die zu eruptiv-feindseliger Aktion aufbricht, wenn der Avatar sich nähert. Die andere Möglichkeit, wie die Spielwelt zum Leben erwachen kann, verbindet sich, ich habe es bereits erwähnt, mit den NPCs, die ja in der Regel mehr oder weniger gesprächsbereit sind. Die hieraus resultierenden Dialoge erzeugen aber meist ebenfalls ein Gefühl der Unheimlichkeit, vielleicht gar der Beklemmung oder der Hoffnungslosigkeit, wenn in ihnen wiederum andere Seinsmöglichkeiten aufscheinen, die indessen stets einem unerreichbaren Anderswo, einer unwiederbringlich verlorenen Vergangenheit oder einer unberührbaren Zukunft angehören.

Ein geradezu erschütterndes Beispiel für diese Art von Figurenkonstruktion bietet Benhart of Jugo aus DARK SOULS II. Dieser mitunter kumpelhaft-freundliche Ritter erklärt dem Spieler:

63 Nebenbei sei darauf hingewiesen, dass die Stasis der Welt von DARK SOULS auch, was die einzelnen Gebiete betrifft, nicht absolut ist. Bestimmte Handlungen des Spielers können sie mitunter aufbrechen. Zerstört man beispielsweise die Illusion der „Sunlight Princess“ Gwynevere, senkt sich Zwielicht über die davor im Sonnenglanz erstrahlende Götterstadt Anor Londo. 
I journeyed from the distant east to perfect my swordsmanship. Legend has it that powerful beings slumber in this land. This sword, it's been in my family for generations. And only a real man can wield it true. I may face any manner of man or beast, but none shall be a match for my sword.

Bei anderer Gelegenheit behauptet er: „They say it is crafted with moonlight, and we all know what that means, it wards off evil. And I would nae trade her for all the riches in the world. They say that no man has ever teased oot the sword's true power. But in the right hands ... “ Nun verhält es sich so, dass Benhart, wann immer ihm der Spieler begegnet, weit davon entfernt ist, mit seinem angeblich so machtvollen Schwert irgendwelche furchteinflößenden Ungeheuer zu bekämpfen. Stattdessen pflegt er dumpf-brütend irgendwo herumzusitzen und überhaupt nichts zu tun - in peinlichem Widerspruch zu seinen markigen Worten. Darüber hinaus gibt es einen anderen NPC, Maughlin the Armourer, der dem Spieler, wenn er Benharts Schwert zu ihm bringt, erklärt, dass dieses keineswegs über besondere Kräfte verfügt. Wirklich bedrückend ist aber, dass man Benhart auch in „Memory of Orro“ begegnen kann, einem Abschnitt des Hauptspiels, der den Avatar weit in die Vergangenheit führt. Hier stellt man fest, dass sich, im Vergleich zur Gegenwartsebene von DARK SOULS II, nichts am Auftreten des Ritters geändert hat; seine Haltung und Redeweise bleiben sich gleich. Also begreift man, dass Benharts Queste immer schon angedauert hat und immer schon gescheitert war: Er ist gleichsam eingesperrt in einer unabänderlichen Hölle der Verleugnung, die psychologisch freilich weder erklärt noch aufgelöst werden kann.

Allerdings ist nicht nur die untote Zeit in der Makroorganisation der Spielwelt gestaltet, sondern ebenso jenes gebieterische „Jetzt!“, welches das Kampfsystem und die Erkundung der einzelnen Gebiete prägt. Es findet seinen strukturellen Ausdruck in den Abkürzungen, die räumliche Zusammenhänge in der labyrinthischen Spielwelt ganz plötzlich greifbar werden lassen, häufig verbunden mit der Freude, die sich dem unverhofften Zugang zu einem Leuchtfeuer verdankt. Es findet seinen Ausdruck darüber hinaus in dem Umstand, dass der Übergang zwischen zwei Gebieten, wie Schotten beschreibt, stets nur punktuell möglich ist, womit häufig eine jähe Veränderung der topografischen Beschaffenheit, des Lichts und der allgemeinen Atmosphäre einhergeht: etwa, wenn man vom „Undead Parish“ in den „Darkroot Garden“ kommt oder, in DARK SOULS III, die düster-klaustrophobischen „Catacombs of Carthus“ verlässt und vor sich den eisigen Zauber der an Andersens Kunstmärchen Sneedronningen (Die Schneekönigin, 1844) gemahnenden Winterstadt „Irithyll of the Boreal Valley“ aufscheinen sieht.

Die beiden letztgenannten Aspekte verdeutlichen zudem, dass und inwiefern jene Spannung zwischen einer zyklischen und einer nach vorne drängenden 
Zeitlichkeit in die Struktur der Spielwelt als solcher eingeschrieben ist, also bis zu einem gewissen Grad unabhängig von den Erkundungsleistungen oder der Erkundungsunlust einzelner Spieler besteht. Man könnte sagen, dass die Kreisbewegungen, die mit dem Verlust der Übersicht einhergehen, unvermeidlich aus der Levelarchitektur resultieren, gewissermaßen also objektiver Teil der Welt von DARK SOULS sind, und dasselbe gilt für die vektorielle Engführung der Spielwelt im punktuellen Übertritt von einem Gebiet zum anderen. Es gilt zuletzt für die Einfaltungen der Welt, die sich vollziehen, wenn eine Abkürzung gefunden, eröffnet und beschritten wird - denn für das Spielgefühl meint eine solche Einfaltung nichts anderes als ein jähes Greifbar-Werden eines Weltzusammenhangs. Weshalb dann jede Bewegung, auch wenn sie an bereits bekannte Orte zurückführt, nach vorne gerichtet scheint.

\section{... stets das Gute will und stets das Böse schafft}

Im Zusammenhang mit dem Genre des Action-RPG war von drei wesentlichen Spieleraktivitäten die Rede. Nachdem ich bislang untersucht habe, was es in DARK SOULS mit dem „Kämpfen“ und dem „Erkunden“ auf sich hat, soll es nun um das „Nachdenken“ gehen. Selbstredend ist keine wie immer geartete Beschäftigung mit einem Videospiel (oder irgendeinem anderen Medium) ohne zerebrale Aktivierung denkbar. Doch das Denken der Spielerinnen und Spieler bezieht sich in DARK SOULS auf ein spezifisches Verhältnis zu dem Spiel. Es betrifft also nicht zuvörderst die Frage, welchen Schwerpunkt man bei der Entwicklung des Avatars setzt; ebenso wenig zielt es auf narrativ orientierte Entscheidungen, die man im Lauf eines Durchgangs zu treffen hat: ob etwa das „Crest of Artorias“ die 20.000 Seelen wert ist, die der Schmied Andre of Astora (in DARK SOULS I) dafür verlangt; oder welche Antwort man geben soll, wenn eine wenig vertrauenserweckende Gestalt, auf die man inmitten einer finsteren Grabkammer trifft, wissen möchte, ob man ein Kleriker sei oder nicht. ${ }^{64}$ Die Fragen und Entscheidungen, mit denen DARK SOULS den Spieler konfrontiert, können zwar einiges Kopfzerbrechen bereiten, sind aber - zumindest auf der bisher anvisierten Ebene - im Wesentlichen generisch. Das heißt, sie sind nicht auf Spezifika des Spieldesigns von Hidetaka Miyazaki zurückzuführen, sondern

64 Dergleichen kann einem in der „Tomb of the Giants“ aus DARK SOULS I geschehen, wobei bereits der Name des entsprechenden NPC, Trusty Patches, anzeigt, dass Misstrauen in der Tat am Platz ist. 
haben ihre Entsprechung in zahllosen anderen Action-RPGs, Action-Adventures und Rollenspielen.

Etwas sehr Besonderes, vielleicht sogar Einmaliges, kommt hingegen da ans Licht, wo DARK SOULS den Spielerinnen und Spielern die Möglichkeit gibt, ihre eigene Haltung zu der Spielwelt spielend $\mathrm{zu}$ vertiefen und zu verändern. Dabei wird ein Modus des genuin ästhetischen Denkens aufgerufen, der eng daran geknüpft ist, wie DARK SOULS seine Geschichte erzählt - oder eben nicht erzählt.

Was soll das bedeuten? Um dies zu erläutern, möchte ich zunächst kurz auf die Makrostruktur der Spielwelt zurückkommen. In seiner Analyse von DARK Souls verdeutlicht Raphael Schotten, wie die das Spiel prägende „Raum- und Bewegungslogik“ zu denken sei, indem er zum Bild eines Zylinders greift,

in dem sich ein Sammelsurium von Kugeln befindet. Der Inhalt der einzelnen Kugeln oder Sphären - ist diskret und homogen innerhalb der jeweiligen Sphäre, jedoch bis zu einem gewissen Grad heterogen, wenn man die Gesamtsumme der Sphären betrachtet. Der Umfang der Sphären ist geringer als jener des Zylinders, somit ergibt sich keine linear vertikale Anordnung. Die Bewegung des Spielercharakters durch diese Konfiguration findet nun in einer Spiralbewegung statt, die ausschließlich an den Berührungspunkten der Sphären von der einen in die andere verlaufen kann. ${ }^{65}$

Wichtig ist hier, dass die einzelnen Sphären als transparent gedacht werden sollten. Das bedeutet, dass sich DARK SOULS in dieser Struktur der Bewegungsidee von Spielen wie THE WITCHER 3 einerseits annähert, insofern beispielsweise schon vom „Firelink Shrine“ aus - dem Gebiet, in das der Spieler unmittelbar nach dem Prolog des Trilogieauftakts gelangt - der Glockenturm der „Undead Parish“ zu erkennen ist, welchen man erklimmen muss, um die erste „Bell of Awakening“ zu läuten. Andererseits bedeutet diese vermeintliche Annäherung jedoch auch eine entschiedene Abkehr von einer Bewegungsidee, die auf Planbarkeit, Linearität und Naturalismus setzt. Schotten führt aus:

Potenziell wird dem Operator sogar klar, dass dies der Zielpunkt der von hier aus angestrebten Bewegung ist - es lässt sich jedoch aus dieser Blickachse keine Aussage über die Natur der Bewegung oder die Dramaturgie der Reise ableiten, die auf diesen Blick folgt, da diese Bewegung nicht der Bewegungslogik der Reise folgt. ${ }^{66}$

Das hier entfaltete „Einerseits-Andererseits“ ist von zentraler Bedeutung für die Poetik von DARK SOULS. Alles ist klar, einfach und und eindeutig; zugleich ist

65 Schotten: All Lands Meet at the End of the Earth, S. 21.

66 Schotten: All Lands Meet at the End of the Earth, S. 21-22. 
nichts klar, einfach und eindeutig. ${ }^{67}$ Ein schönes Beispiel für diese Einfachheit und Klarheit ist nicht zuletzt die erste „Bell of Awakening“ selbst. Wie Jason Killingsworth beschreibt, liegt der Gedanke nahe, diese Bezeichnung auf jene „reflexive convention of the fantasy genre“ zurückzuführen, die auch Namen wie „Boots of Swiftness, Helmet of Clarity, Tunic of Luminescence“ hervorbringen könnte. ${ }^{68}$ Doch weit gefehlt:

Only once you've rung the Bells of Awakening [...] does a giant perched atop the fortress [gemeint ist „Sen's Fortress“] draw up the front gate by tugging an enormous chain-link pulley $[. .$.$] the ,awakening' in question refers to the literal rousing of the only creature$ strong enough to permit entry. ${ }^{69}$

Der Einfachheit und Klarheit steht aber, wie gesagt, eine große Rätselhaftigkeit gegenüber, die die Welt von DARK SOULs bis in den letzten Winkel durchdringt und schwer nur - wenn überhaupt - aufzulösen ist. Meist realisiert sich dieses Spannungsverhältnis in einer Verwobenheit von Evidenz und Enigmatik. In Schottens Beispiel wird dies daran deutlich, dass die vermeintlich transparente Weltgestaltung in eine verworrene Komplexität umschlägt, wenn es um die konkrete Anordnung der einzelnen Gebiete und die damit verbundenen Fragen der Wegfindung geht. Ähnliches lässt sich für Killingsworths Überlegungen zu den „Bells of Awakening“ sagen. Zwar begreift man bald, dass ihr obskur (oder schlicht kitschig) anmutender Name ganz wortwörtlich zu deuten ist; weit mehr Mühe macht es allerdings, die Frage zu beantworten, warum die Glocken sich hoch oben im Turm der „Undead Parish“ und tief unter der Erde im Reich der Chaoshexe Quelaag befinden; wer sie dort hingetan und den Giganten auf den Mauern von „Sen’s Fortress“ zu seinem Dienst bestellt hat.

Wie ich bereits anfangs angedeutet habe - unter Rückgriff auf Andreas Inderwildis Beschreibung der Mythologie von DARK SOULS -, gilt diese eigentümliche Verwobenheit von Evidenz und Enigmatik ebenso für die Narration des Spiels. Auch hier gönnt sich Miyazaki eine Klarheit, die man je nach Geschmack klischeehaft oder hellsichtig finden kann: Das Königreich Lordran ist

67 „Meanwhile, the guideposts through your journey have basic, humble descriptions. You have to ring the bell. You have to light the bonfires, and then kindle them. Everything is called what it is, and even the levels have short, simple names. Slapping ornate names onto everything - say, the Bell of Qualla'goggooo, the Bonfire of Shamalama - would, in trying to layer on meaning, merely slop on too much and disturb the beauty of what's in front of you." Dahlen: What DARK SOULS Is Really All About.

68 Jason Killingsworth: Sen's Fortress. In: MacDonald/Killingsworth (Hg.): You Died, S. 117-120, hier: S. 118.

69 Killingsworth: Sen’s Fortress, S. 118. 
durch das schuldhafte Vergehen seiner Herrscher einem Fluch verfallen, den es nun $\mathrm{zu}$ brechen gilt. Doch auch hier ist dem Fragen kein Ende, wenn man es erst einmal unternimmt, die Angelegenheit in allen Einzelheiten zu ergründen: Welche Schuld genau hat Gywn, Lord of Sunlight, auf sich geladen? Warum ist Anor Londo, die Stadt, in der er einstmals herrschte, noch immer in strahlendes Licht getaucht, steht da in majestätischer Unberührtheit, wenn Düsternis und Verfall das restliche Lordran zu verschlingen drohen? Welche Rolle spielen die Verbündeten Gwyns, mit deren Hilfe er einstmals die Drachen bezwang, etwa Seath the Scaleless, selbst ein Drache, der allerdings längst schon - warum gleich? - dem Wahnsinn verfallen ist? Und was hat es mit all den merkwürdigen Gestalten auf sich, denen der Spieler auf seinen Reisen begegnet und deren Verhalten mitunter bis zur Verstörung erratisch anmutet? Warum, zum Beispiel, verrät Petrus of Thorolund seinen Schützling, die Klerikerin Rhea of Thorolund - zuerst lässt er sie allein und hilflos in der „Tomb of the Giants“ zurück, dann will er sie umbringen -, nachdem er doch anfangs vor Sorge um das Wohlergehen der jungen Frau zu zerfließen schien? Ist er einfach ein heimtückischer Lügner, oder verbirgt sich etwas anderes hinter seiner Boshaftigkeit?

Tatsächlich kann man zahllose Stunden damit verbringen, im Internet die verschiedenen Rekonstruktionsversuche zu bestaunen, die DARK-SOULS-Fans unternommen haben, in Texten, Wikis, Guides, Chats und Videos, um die genannten Fragen, und wohl Hundert mehr noch, zu beantworten. ${ }^{70}$ Ich will diesen Versuchen keinen weiteren hinzufügen. Aus meiner Sicht spricht es für die Präzision und künstlerische Meisterschaft des Spieldesigns von Hidetaka Miyazaki und seinen Mitarbeitern, dass man die affektpoetische Volte von DARK SOULS in jedem Augenblick spürt, im atmosphärischen Gepräge der Räume, der Gestaltung der Gegner, dem erbarmungslosen Schwierigkeitsgrad, selbst wenn man keine Sekunde darauf verwendet hat, die Rätsel der Narration zu ergründen - jene Volte nämlich, dass Lordran von einer Kraft beherrscht wird, die, in Umkehrung von Goethes berühmtem Diktum, stets das Gute will und stets das Böse schafft. ${ }^{71}$

70 Wer sich mit einer solchen Rekonstruktion in Buchform beschäftigen möchte, sei auf die entsprechenden Kapitel von Keza MacDonalds und Jason Killingsworths inoffiziellem Kompendium verwiesen: „The Lore Wrestle. An Intro to DARK SOULS Lore“ sowie „Character-Building. Meet the Cast of DARK SOULS“. Vgl. MacDonald/Killingsworth (Hg.): You Died, S. 282-287 u. 298-327.

71 Ich beschränke mich hier auf Anmerkungen zu der Handlung und dem Hintergrund von DARK SOULS I. Mir scheint aber, dass die beschriebene affektpoetische Volte desgleichen die Narration, und eben letztlich das gesamte Spielgefühl, des zweiten und dritten Teils der Trilogie bestimmt, obgleich das verfluchte Königreich hier nicht Lordran heißt, sondern Drangleic (DARK SOULS II) beziehungsweise Lothric (DARK SOULS III). 
Damit soll nicht behauptet werden, dass es überflüssig wäre, nach der inneren Logik der Welt von DARK SOULS, den Motiven und dem Schicksal wesentlicher Figuren $\mathrm{zu}$ fragen. Tatsächlich erscheinen derartige Fragen in diesem Spiel weit dringlicher als in vielen Romanen und Filmen, geschweige denn anderen Fantasy-Videospielen. Das liegt vermutlich daran, dass die Durchleuchtung narrativer Feinheiten im Fall von DARK SOULS letztlich nicht nur, und auch nicht vorwiegend, dazu dient, die eigene Neugierde $\mathrm{zu}$ befriedigen oder das Spiel in einem abstrakten Sinn ,besser zu verstehen“. Vielmehr geht es, so meine ich, den Spielerinnen und Spielern darum, die eigene Spielerfahrung mit der objektiven Verfasstheit der DARK-SOULS-Welt zu verweben, sie mithin zu reflektieren und zu vertiefen. So lässt sich der Genuss, den das Spiel verschafft, und zwar nicht zuletzt im intensiven Erleben konfligierender Zeitlichkeiten, über dessen Grenzen hinaus verlängern, hinein in die Metatexte und das alltägliche Leben. Aber noch die Spielerfahrung selbst wandelt sich in der Reflexion, die DARK SOULS über die Ergründung seiner Rätsel und Geheimnisse anbietet. Oder andersherum: Wer die Fragmente zusammensetzen will, die vielleicht am Ende eine Abfolge mosaikhafter Bilder ergeben, welche die Historie der Spielwelt ebenso wie der sie prägenden Gestalten aufschließt - wer dies also unternehmen will, muss DARK SOULS auf eine bestimmte Art spielen.

Keza MacDonald erläutert, was das bedeudet:

DARK SOULS' story took months - even years - to fully uncover. It required careful excavation. This is because enjoying DARK SOULS' story is not a passive experience; it's not told to you. You have to find it. You have to search for hints in item descriptions, in the sparse snippets of dialogue, in your surroundings, in the forms and lairs and implied histories of the bosses you encounter, in the game's one and only narrative cutscene (the prologue). ${ }^{72}$

Und sie fährt fort:

An especially interesting aspect of DARK SOULS' story is that it could only be told through a video game, making it almost unique. It tells us very little through the mediums of text or film, and vast amounts through context, exploration and environmental storytelling that simply would not be possible in any other format. ${ }^{73}$

72 Keza MacDonald: The Lore Wrestle. An Intro to DARK SOULS Lore. In: MacDonald/Killingsworth (Hg.): You Died, S. 282-287, hier: S. 282-283.

73 MacDonald: The Lore Wrestle, S. 283-284. Auch Nils Gelker betont die aktive Rolle der Spielerinnen und Spieler bei der Aufdeckung der Narration von DARK SOULS - und verweist im selben Zug darauf, dass das Spiel einen Modus des Erzählens entwickelt hat, der als in hohem Maße medienspezifisch gelten kann: „DARK souls ist kein Text, der duch eine jahrhundertelange Überlieferungsgeschichte zu heilende (Text-)Verderbnisse aufweist. Vielmehr führt die konsequente Verweigerung konventioneller Narrativität zu einer Restrukturierung narrativer Bedeutsamkeit in den typischerweise ludischen Bereich. Da auf der diegetischen Ebene keine 
Aus dieser Perspektive ist eine spezifische Wechselwirkung zwischen dem Modus des Spielens und dem Spielgefühl zu konstatieren, die keineswegs in dem aufgeht, was allgemein - also bezogen auf jedes beliebige Videospiel über die Interaktion zwischen Spieler und Medium gesagt werden könnte. In DARK SOULS verhält es sich nämlich so, dass die Erfahrungsqualität der komplexen und konflikthaften Zeitlichkeiten, die das Spiel gestaltet, noch einmal sich intensiviert, wenn man spielend verstehen will, welche Geschichte (in beiderlei Sinn: Historie und Erzählung) die Welt geprägt hat, die man durchwandert. Da, wie MacDonald erläutert, sämtliche Spieleraktivitäten, das Kämpfen, die Erkundung, die Interaktion mit den Nichtspielercharakteren und die Wahl der Ausrüstung, in diesen Prozess einbezogen sind, betrifft jene Intensivierung folglich auch sämtliche Zeitlichkeiten, die DARK SOULS konfiguriert, indem es die verschiedenen Dimensionen der Spielerfahrung entfaltet; die Zeiten des Stillstands, des Ausharrens und der zyklischen Wiederholung sind ebenso betroffen wie die Zeiten des Vorwärts-Drängens und des gebieterischen „Jetzt!“. Anders ausgedrückt: Die Zeiterfahrungen sind den Spieleraktivitäten eingestaltet und finden gleichsam einen verstärkenden Widerhall in den raum-zeitlichen Tiefen der Spielwelt. ${ }^{74}$

Versuchen wir, noch genauer zu verstehen, was - abgesehen von jener Intensivierung der Zeitlichkeitserfahrung - der Gewinn ist, wenn man sich auf die Rekonstruktionsarbeit einlässt, die das langsame, stückweise Zusammensetzen der Welt von DARK SOULS erfordert. Zunächst erhält man natürlich Kenntnis der vielen kleinen und großen Geschichten, die der Spielwelt eingeschrieben sind. Diese Geschichten sind, wie gesagt, nicht einfach nur lehrreich bezogen auf das Verhängnis, dem Lordran und seine Bewohner anheimgefallen sind; in immer

Instanz die Integration dieser Informationen leisten kann, wird die systematische Sammlung und Bewertung aller zugänglichen Informationen provoziert. Die SpielerInnen müssen zu Philologen werden." Nils Gelker: Fantasy-Philologie. Wie DARK SOULs narrative Bedeutung erzeugt. In: Rudolf Thomas Inderst/Pascal Wagner/Christof Zurschmitten (Hg.): Prepare to die! DEMON SOULS, DARK SOULS und BLOODBORNE. Glückstadt 2019, S. 15-32, hier: S. 29.

74 Ein ähnlicher Gedanke findet sich bei Franziska Ascher: „Die Spielwelt DARK SOULS ,erzählt‘ jedoch nicht nur punktuell von Ereignissen, die sich in ihr abgespielt haben (könnten), sondern auf einer Meta-Ebene auch davon, mit was für einer Art Spiel man es hier zu tun hat. Denn der Schwierigkeitsgrad von DARK SOULS spiegelt sich ebenso in der radikal vertikalen Gliederung der Spielwelt wie in den zahlreichen freischaltbaren Abkürzungen, welche im endlosen Kreislauf von Tod und Respawn die Rückkehr zu den als Speicherpunkte fungierenden Leuchtfeuern erleichtern, und gibt darin Aufschluss darüber, was für eine Art Geschichte in DARK SOULS erzählt wird: Ein melancholisches Dark-Fantasy-Epos, in dem Gut und Böse eine Frage der Perspektive sind und die Möglichkeit eines ,Happy End“ grundsätzlich in Frage gestellt wird.“ Ascher: Die Narration der Dinge Teil II. 
neuen Variationen, Spiegelungen und Brechungen umkreisen sie die beschriebene affektpoetische Volte, sodass sich im Spielgefühl zur drückenden Gewissheit verdichtet, was zunächst eine - freilich allgegenwärtige - atmosphärische Ahnung war: In DARK SOULS schafft das Licht die Dunkelheit.

Betrachten wir ein Beispiel, das sich auf die Gegenstände bezieht, die man in DARK SOULS entdeckt. Diese sind

in der Spielwelt nur als denaturierte Abstraktionen - in Form eines diffus leuchtenden Balls - repräsentiert. Nachdem der fragliche Gegenstand per Knopfdruck aus der als digitale Architektur manifestierten Welt entfernt wurde, wird er in ein - im Gegensatz zur räumlich erfahrbaren Welt - vollkommen zweidimensionales und abstrahiertes Verwaltungssystem eingegliedert, das nur in dezidiert außerhalb der Diegese existierenden Menüs eingesehen werden kann. Bis zur Anwendung ihrer Funktion verschwinden die Gegenstände hiermit vollkommen aus dem diegetischen Raum. In diesem Moment erhalten sie jedoch die auf das Engste mit der Diegese verknüpfte Eigenschaft, dass der Beschreibungstext des jeweiligen Gegenstandes einsehbar wird. ${ }^{75}$

Diesen Beschreibungstexen lassen sich einerseits „praktische Anwendungstipps entnehmen [...] wie etwa die lebenswichtige Information, dass nur Moosklumpen mit Blume eine Vergiftung durch Toxin heilen“"76; andererseits geben sie in vielen Fällen eine Auskunft über den Hintergrund des entsprechenden Gegenstands oder seines früheren Besitzers. Franziska Ascher stellt fest, dass die kleinen Geschichten über die meist verstorbenen Eigentümer einer bestimmten Waffe oder Rüstung - über ihre Herkunft, ihre Persönlichkeit und ihre Motive -, „nicht als Tatsachen, sondern als Mutmaßungen wiedergegeben werden". 77

Aus dieser Beobachtung folgert sie:

Es gibt also eine Erzählstimme, und diese ist zwar auktorial, aber nicht allwissend. Die Itembeschreibung wird folglich als fragmentarisch und möglicherweise sogar unzuverlässig ausgestellt. [...] Dorrit Cohn beschreibt einen unzuverlässigen Erzähler als jemanden, der unfähig oder unwillig ist, zu erzählen, was ,wirklich“ passiert ist. Beides ist im Falle des Itemerzählers denkbar, da seine narrativen Angaben große Lücken aufweisen und in einigen seltenen Fällen sogar mit den beobachtbaren Gegebenheiten der Spielwelt kollidieren. $^{78}$

75 Raphael Schotten: All Lands Meet at the End of the Earth, S. 12.

76 Franziska Ascher: Die Narration der Dinge Teil I. Items. In: Paidia. Zeitschrift für Computerspielforschung, 22. September 2014, http://www.paidia.de/die-narration-der-dinge-teil-i-2/ [letzter Zugriff: 12.05.2020].

77 Ascher: Die Narration der Dinge Teil I.

78 Ascher: Die Narration der Dinge Teil I. 
Was das wiederum bedeutet, erläutert Ascher am Beispiel des Knight of Thorns Kirk, einem Nichtspielercharakter aus DARK SOULS I. Selbiger wird

in der Beschreibung seiner Rüstung als „Finstergeist“ bezeichnet, was ihn als Anhänger der Urschlange Kaathe ausweist. Nachdem ihn der Spieler dreimal besiegt hat, findet man seine Leiche jedoch am verborgenen Leuchtfeuer von Quelaags Schwester, einer der Töchter des Chaos, die der Hexe von Izalith folgten. War Kirk also in Wahrheit ein Diener der todkranken Chaostochter? Und verbargen sich hinter seiner furchterregenden Rüstung am Ende gar gute Absichten? Denn die Diener des Chaos kämpfen ihrem Eid gemäß nur, um mit der Menschlichkeit ihrer getöteten Gegner die Qualen ihrer „Fair Lady“ zu lindern. Dies würde einen Pakt Kirks mit Kaathe ausschließen, der von seinen Anhängern zwar ebenfalls Menschlichkeit verlangt, jedoch für weit finsterere Zwecke. Natürlich beweist der Fundort von Kirks Leiche nichts, er gibt jedoch zu denken, da Items in DARK SOULS auch in anderen Fällen nicht nur unter Gameplay-, sondern auch unter Story-Aspekten platziert sind. $\mathrm{Ob}$ der oder die Itemerzähler also tatsächlich unzuverlässig oder nur schlecht informiert ist/ sind, lässt sich folglich nicht letztgültig klären. In jedem Fall aber verleiht die Lokalisierung der Dornenrüstung Kirk einen narrativen Horizont, der deutlich über seine Titulierung als „der mörderische Kirk“ in der Rüstungsbeschreibung hinausgeht. ${ }^{79}$

Die Überlegungen von Franziska Ascher sind in verschiedener Hinsicht aufschlussreich: Zum einen verdeutlichen sie, wie die wechselseitige Durchdringung der Zeitlichkeiten (hier jene des Erforschens) und der langsamen Rekonstruktion der Spielwelt funktioniert: Zwischen den Kämpfen mit dem Dornenritter wird in der Regel manche Stunde vergehen, da eines der drei Gebiete, in denen er angreift, weit von den beiden übrigen entfernt ist (bei ihnen handelt es sich um die „Depths“, die „Demon Ruins“ und „Lost Izalith“); hat man Kirk endgültig besiegt, liegt seine Rüstung, Ascher weist darauf hin, wiederum in einem anderen Gebiet (nämlich „Quelaag's Domain“), sodass man sie eher zufällig und mitunter gar nicht finden wird. Einmal mehr steht also der endlosen Abfolge von Wiederholungen im Zyklus von „effort, frustration, reward and release“ ein „Jetzt!“ gegenüber, wenn im Moment des Auffindens der Rüstung eine Erkenntnis über die möglichen Zusammenhänge innerhalb der Spielwelt aufblitzen mag.

Derartige Erkenntnisse können sich durchaus epiphanisch anfühlen, bleiben jedoch zumeist - eben auch von Spielerseite - Mutmaßungen, die der Fragwürdigkeit nicht entraten. Zwangsläufig ist dem so, wenn man Ascher in der Charakterisierung des Itemerzählers folgt, der ihr ja als unzuverlässig oder schlecht informiert gilt. Wichtig ist nun, dass das Zweifelhafte der meisten Einsichten, die sich auf die Welt von DARK SOULS, ihre Geschichte und ihre Bewohner beziehen, nichts daran ändert, dass sie eine beträchtliche Auswirkung auf

79 Ascher: Die Narration der Dinge Teil I. 
das Spielgefühl haben. Jede für sich genommen, vor allem aber in ihrer Gesamtheit bestätigen und verstärken sie den Eindruck einer unentrinnbaren Fluchhaftigkeit, welcher aus der affektpoetischen Gerichtetheit von DARK SOULS resultiert. Umgekehrt könnte man sogar behaupten, dass es gerade das Fragwürdige, Nebulöse, Uneindeutige, Verschattete und Flüchtige an jenen Erkenntnissen ist, was sie so wirkmächtig macht; aufgrund dieser Eigenschaften fügen sie sich nämlich nahtlos in das restliche Spieldesign ein, erweisen sich gewissermaßen als kognitive Entsprechung zu der Verworrenheit der Wege, die die Welt von DARK SOULS durchziehen, zu dem Brüchigen und Trügerischen, das sie allzeit gefährlich macht; zu dem Zwielicht, das die Gassen, Häuser, Gänge und Türme einhüllt; zu dem gnadenlosen Schwierigkeitsgrad, der dafür sorgt, dass man selbst an Stellen, die längst gemeistert schienen, in einem unaufmerksamen Moment sterben kann, sodass das vermeintlich Gewisse und Festgefügte immer wieder zweifelhaft wird.

\section{Unausweichliche Verstrickungen}

Aus all diesen Gründen kann man behaupten, dass mit dem Versuch, die Geheimnisse von DARK SOULS zu lüften, eine Sensibilisierung einhergeht, die einem Aspekt der Weltgestaltung gilt, in dem die Affekpoetik des Spiels vielleicht ihren höchsten, sicherlich jedoch ihren beunruhigendsten Ausdruck findet. Es erweist sich nämlich, dass auch der Spieler (respektive der Avatar) nicht unberührt bleibt von dem Fluch, der die Königreiche der DARK-SOULS-Trilogie, Lordran, Drangleic und Lothric, in die Finsternis gestürzt hat.

Dass man Kirk töten muss, um an seine Rüstung und seine Waffe zu kommen, mag ja noch angehen; schließlich ist er es, der den Spieler attackiert. Aber der Knight of Thorns ist kein Einzelfall. „Ein Wesen zu verstehen, bedeutet in DARK SOULS häufig, es zu töten“, ${ }^{80}$ schreibt Ascher.

Sie führt aus:

Oft weiß man wenig bis nichts über einen Gegner (oder auch einen NPC), ehe man ihn besiegt hat. Die Kämpfe selbst sind meist eine langwierige Sache, denn durch den hohen Schwierigkeitsgrad des Spieles kann der Spieler erst dann den Sieg erringen, wenn er den Gegner genau kennt - jede seiner Bewegungen, jeden seiner Angriffe. Und ist der Feind schließlich tot, erfährt man aus der Beschreibung seiner Seele oder seiner persönlichen Besitztümer, wer er war und häufig auch die Details seiner Geschichte. Doch auch wenn der Spieler die Hintergründe seiner Feinde zuvor gekannt hätte - wie es bei Spielern im New Game Plus Modus ja größtenteils der Fall ist - hätte er doch nicht anders handeln können,

80 Ascher: Die Narration der Dinge Teil I. 
denn es gibt keinen anderen Weg, um im Spiel einen Fortschritt zu erzielen. [...] Die Perspektive des Spielers ähnelt der eines Biologen, der ein Lebewesen zwar beobachten kann, um Informationen über es zu sammeln, es jedoch sezieren muss, um seiner Natur auf den Grund zu gehen - und den Gegenstand seines Interesses dadurch unwiderruflich zerstört. ${ }^{81}$

Ascher verbindet diese Zwangsläufigkeit im Spielablauf mit dem „Reuepotenzial“ von DARK SOULS. ${ }^{82}$ Nun mag man einwenden, dass das ja für nahezu alle Videospiele zutreffe; schließlich gibt es kein anderes Medium, das sich derart obsessiv dem Kämpfen, Töten und Sterben in allen denkbaren Variationen widmet. Der Unterschied besteht allerdings darin, dass die meisten Spiele - zumal, wenn es sich um sogenannte Triple-A-Produktionen handelt - die unangenehmeren Implikationen der endlosen Blutbäder geflissentlich ausblenden. Sehr deutlich ist das etwa in der UNCHARTED-Reihe (Naughty Dog, 2007-2017) ${ }^{83}$ oder der jüngsten TOMB-RAIDER-Trilogie (Crystal Dynamics, 2013-2018) ${ }^{84}$. Deren Protagonisten, Nathan Drake beziehungsweise Lara Croft, sind ja sehr dezidiert als moralisch integre Figuren gezeichnet (wenngleich Drake einem verwegen-unbeschwerten Halunkentum zuneigt und Croft beim Versuch, ihren Vater zu rächen, versehentlich den Weltuntergang heraufbeschwört); was sie allerdings nicht daran hindert, im Lauf ihrer Abenteuer ganze Hundertschaften von Gegnern niederzumetzeln. ${ }^{85}$ Es

81 Ascher: Die Narration der Dinge Teil I [Herv. i. O.].

82 Vgl. Ascher: Die Narration der Dinge Teil I.

83 Im Einzelnen handelt es sich um die Spiele: UNCHARTED: DRAKE'S FORTUNE (2007), UNCHARTED 2: AMONG THIEVES (2009), UNCHARTED 3: DRAKE'S DECEPTION (2011), UNCHARTED: GOLDEN ABYSS (2012) UNCHARTED: FIGHT FOR FORTUNE (2012), UNCHARTED 4: A THIEF'S END (2016) und UNCHARTED: THE LOST LEGACY (2017).

84 Die Reboot-Trilogie umfasst: TOMB RAIDER (2013), RISE OF THE TOMB RAIDER (2015) und SHADOW OF THE TOMB RAIDER (2018).

85 René Glas hat nicht zuletzt die UNCHARTED-Spiele und ihren Helden im Blick, wenn er derartige „inconsistencies between a game's narrative and gameplay“ als „ludonarrative dissonance“ definiert. Dieser - dem Spieledesigner und -kritiker Clint Hocking entlehnte - Begriff zielt auf ,potential aesthetic but also ethical illogicalities in the way a game is designed and/ or experienced“. Vgl. René Glas: Of Heroes and Henchmen. The Conventions of Killing Generic Expendables in Digital Games. In: Torill Elvira Mortensen/Jonas Linderoth/Ashley ML Brown (Hg.): The Dark Side of Game Play. Controversial Issues in Playful Enviroments. New York/ Abingdon 2015, S. 33-49, hier: S. 33-34. Vgl. auch: Clint Hocking: Ludonarrative Dissonance in BIоsноск. In: Click Nothing. Design from a Long Time Ago, 07. Oktober 2007, http://clickno thing.typepad.com/click_nothing/2007/10/ludonarrative-d.html [letzter Zugriff: 12.05.2020].

Ich danke Lars Dolkemeyer für den Hinweis, dass man in den frühen TOMB-RAIDER-Spielen nicht nur die unvermeidlichen „Bad Guys“, sondern ständig auch Tiere wie Tiger, Schneeleoparden, Krokodile oder sogar Dinosaurier über den Haufen schießt, weil diese die eindeutig in ihr Habitat eindringende „Archäologin“ angreifen - wobei die meisten der genannten Tierarten wohlgemerkt vom Aussterben bedroht oder, im Falle der Dinosaurier aus dem ersten Teil 
geht mir nicht um eine moralische Kritik dieses oder jenes Spieles. Wohl aber darum, die Differenz zwischen verschiedenen ästhetischen Modi auszumachen.

Und im Fall der DARK-SOULS-Trilogie gilt eben, dass Hidetaka Miyazaki und seine Mitarbeiter sehr viel Mühe darauf verwendet haben, dass sich die Spielerinnen und Spieler ihrer selbst und der Rolle des Avatars nicht zu sicher fühlen. Das betrifft wesentlich das Verhältnis zu den Gegnern, die einem im Laufe der Zeit begegnen: Einige von ihnen sind so drollig, dass man sie eigentlich nicht töten möchte (etwa die Pilz-Männlein in DARK SOULS I, aber auch riesenhafte Ungeheuer wie Sulyvahn's Beasts in DARK SOULS III). Weit häufiger sind Konfrontationen mit Gegnern, die etwas Mitleiderregendes an sich haben (das betrifft beispielsweise die meisten Untoten) und mitunter so erbarmungswürdig sind in ihrem Elend, dass es geradezu beschämend ist, sie zu attackieren (hier denke ich vor allem an die siechen Vogelwesen, die das schneeverwehte Dorf in „Ashes of Ariandel“ bewohnen, einer von zwei Erweiterungen zu DARK SOULS III). Ebenso begegnet man Wesen von bestrickender Schönheit, die sich mal andersweltlich, mal grausig ausnimmt und häufig einhergeht mit einer Anmutung von Unschuld (ein Gestaltungsprinzip, das, wie mir scheint, vorwiegend auf eine Reihe von weiblichen oder geschlechtlich unbestimmten Bossen zutrifft: etwa die Moonlight Butterfly, Chaos Witch Quelaag oder Crossbreed Priscilla in DARK SOULS I; die Dancer of the Boreal Valley in DARK SOULS III; zudem der an die Mythologie des Gefallenen Engels gemahnende Darklurker aus DARK SOULS II und einige mehr). Schließlich gibt es manche Gegner - auch hier haben wir es in erster Linie mit Bossen zu tun -, die von einer dunklen, schmerzlichen Tragik umweht werden. In diesem Zusammenhang ist wohl zuvörderst die Begleiterin des heroischen Ritters Sir Artorias the Abysswalker aus dem ersten Teil der Trilogie zu nennen, der, seiner Tapferkeit zum Trotz, schlussendlich von der Dunkelheit verschlungen wurde. Noch Jahrhunderte nach dem Tod ihres Herrn bewacht Great Grey Wolf Sif dessen Grabstätte; doch der Spieler hat keine andere Wahl, als die Ruhe des Toten zu stören, denn er benötigt einen Ring, den er nur hier finden kann.

Rich Stanton schreibt über die unvermeidliche Konfrontation:

I love the Great Grey Wolf Sif [...]. The fight is one that saddens me. It is a duel to be savoured, a consummation devoutly to be wished. Even the first time, before knowing much at all about DARK SOULS, there was something special about Sif (the wolf's gender is up for debate, incidentally). I reviewed the game back in the day, and so was playing

der Reihe, bereits ausgestorben sind. Retrospektiv könnte es fast scheinen, als würde TOMB RAIDER hier nolens volens eine Annäherung an die Affektpoetik von SHADOW OF THE COLOSSUS vorwegnehmen. 
through weeks before the internet had unravelled Lordran's mysteries. [...] one rumour, since debunked but persisting to this day in dark corners of the community, was that you could somehow save Sif.

You cannot. But DARK SOULS makes you wish you could. [...] Near the end of the fight, exhausted and injured, Sif begins limping - her attacks slower, her grace replaced with fatigued clumsiness, even to the extent she falls over. But she never gives up. You must kill her, and claim your prize. ${ }^{86}$

Aus Stantons Liebeserklärung an die Polygon-Wölfin Sif wird deutlich, dass DARK SOULS durchaus fähig ist, bei den Spielerinnen und Spielern, vielleicht gerade, wenn sie erfolgreich sind, Gefühle von Trauer und Ratlosigkeit und sogar von existenziellem Zweifel hervorzurufen. Das liegt eben nicht zuletzt daran, dass der endlose Überlebenskampf in den verfluchten Königreichen von einer gewissen Absurdität umweht wird: Warum ist nahezu alles, was kreucht und fleucht, darauf versessen, den Avatar umzubringen? Warum hat man selbst keine Wahl, als Leichenberge aufzuhäufen? Was hat man überhaupt in Lordran (oder Drangleic oder Lothric) zu suchen?

$\mathrm{Zu}$ dieser Empfindung von Sinnlosigkeit trägt natürlich bei, dass so vieles in DARK SOULS bis zum Schluss von narrativem und metaphyischem Dunkel umweht bleibt. „Bis zum Schluss“ ist hier wörtlich zu verstehen: Denn die verschiedenen Spielenden sind kaum angetan, Licht in dieses Dunkel zu bringen weder was das erzählerische Verständnis, noch was die atmosphärische Gestimmtheit betrifft. Nachdem Sonnenkönig Gwyn, der letzte Boss also, endlich besiegt ist, haben die Spielerinnen und Spieler nämlich nur die Wahl, entweder den Avatar zu opfern, um die „First Flame“ wieder zu entzünden, oder sich selbst zum „Dark Lord“ eines Zeitalters der Finsternis zu machen. Die Konsequenzen der eigenen Entscheidung sind in beiden Fällen unklar. Erweist sich der Avatar als die Kraft, welche die fluchhafte Verfallenheit der Spielwelt perpetuiert? Oder finden seine Leiden ihren Sinn in der Hoffnung auf eine bessere Zukunft? Es bleibt ungewiss. Denn in DARK SOULS ist der strahlende Glanz des vermeintlich Guten trügerisch und die Dunkelheit möglicherweise der einzige Trost. Doch wie immer sich die Spielerinnen und Spieler entscheiden: Am Ende macht es keinen Unterschied. Es geht ja alles wieder von vorne los, kaum dass der Abspann gelaufen ist, ohne freilich wirklich von vorne loszugehen. Man könnte also vermuten, Lordran werde weder ein neues Zeitalter des Lichts, noch ein Zeitalter der Finsternis je erleben, sondern auf ewig in einem erbarmungslosen Dazwischen befangen sein.

86 Rich Stanton: Becoming the Dark Soul. In: www.eurogamer.net, 19. Januar 2014 [25. Oktober 2012], https://www.eurogamer.net/articles/2012-10-25-becoming-the-dark-soul [letzter Zugriff: 12.05 .2020$]$. 
Unabhängig davon, wie man das Ende von DARK SOULS interpretiert, sollte deutlich geworden sein, dass Hidetaka Miyazaki und seine Mitarbeiter eine Spielerposition gestaltet haben, die darauf abzielt, jeglichen Anflug einer selbstgewissen Rechtschaffenheit zu untergraben. Das betrifft zunächst die Art und Weise, wie in der Konfrontation mit den Gegnern die Notwendigkeit des Kampfes gleichermaßen absolut gesetzt und mit quälendem Skrupel beladen wird. Darüber hinaus unternimmt DARK SOULS mancherlei Anstrengung, die Spielerinnen und Spieler zu Handlungen zu verlocken, die ihrem eigenen moralischen Empfinden nach vermutlich eher anrüchig sind, diegetisch jedenfalls eindeutig so markiert werden. Das gilt für den Umgang sowohl mit Nichtspielercharakteren als auch mit anderen Spielern.

Den erstgenannten Punkt erläutert Franziska Ascher anhand einiger weiblicher Figuren: den Feuerhüterinnen, die über bestimmte Leuchtfeuer wachen, und der bereits erwähnten Klerikerin Rhea of Thorolund. Diesen Figuren ist gemein, dass sie mit gewissen stereotyp-femininen Attributen versehen sind: Sie wollen dem Wohlergehen anderer dienen, strahlen Reinheit und Verletzlichkeit aus, ergehen sich zudem gerne in Reue und Trauer über echte oder eingebildete Verfehlungen. Man könnte sagen, sie haben sich inmitten einer finsteren, blutrünstigen Welt ihre Menschlichkeit bewahrt; wobei diese sittliche Qualität in DARK SOULS mit kurioser Handfestigkeit wortwörtlich verdinglicht, in eine Ware, einen Gegenstand transformiert wird. Die Seelen der Feuerhüterinnen strotzen nämlich, ebenso wie Rheas, vor Menschlichkeit. Das macht sie besonders wertvoll, denn allein Menschlichkeit steht „zwischen dem Avatar und dem gefürchteten Schicksal ,hollow', d. h. zu einer (buchstäblich) seelenlosen Hülle, zu werden“" ${ }^{87}$ Und für den Fall, dass die Spielerinnen und Spieler nicht von selbst merken sollten, dass die wehrlosen Frauenfiguren reiche Beute versprechen, gibt es andere, selbstredend männliche Nichtspielercharaktere, die auf diesen Umstand aufmerksam machen. Zuvörderst ist da der Ritter Lautrec of Carim zu nennen, der sich im Lauf des Spiels als grausamer Frauenmörder entpuppt.

Besonders perfide ist indessen das Verhalten des ebenfalls erwähnten Petrus of Thorolund, der die Spielerinnen und Spieler dazu einlädt, sich in sadistischen Fantasien zu ergehen, was für Quälereien und Demütigungen man der ihm anvertrauten Rhea zufügen könnte, die alleine in den Katakomben zurückgeblieben ist: „In the depths of the Catacombs, M'Lady slipped off the giant's coffin and into a hole. Her two companions are no longer human; and the lass

87 Ascher: Feuerhüterinnen als Kristallisationspunkte des Begehrens. In: Paidia. Zeitschrift für Computerspielforschung, 15. Dezember 2014, http://www.paidia.de/feuerhuter innen-als-kristallisationspunkte-des-begehrens/ [letzter Zugriff: 12.05.2020]. 
weeps in solitude. Right now you could do as you please with her. The poor little purebred is entirely helpless.“

Ascher kommentiert diese ziemlich unverblümte Aufforderung zu Raub, Mord und Vergewaltigung wie folgt:

Menschlichkeit als pseudo-materieller Besitz wird also in semantische Nähe zu Rheas sexuellem Potential gerückt, doch wird sexuelles Begehren gleichzeitig auch als materielles Begehren operationalisiert, da kein sexuelles Interesse von der Spielerseite her nötig ist, um Rhea durch die Augen Lautrecs und Petrus' zu sehen. ${ }^{88}$

Sie fährt fort, indem sie erläutert, dass sich der Spieler zwar von Lautrec und Petrus distanzieren könne, indem er sie moralisch verurteile, der Komplizenschaft mit den beiden aber dennoch nicht völlig entrate, da die Versuchung, Nichtspielercharaktere zu töten, um sich ihre Ausrüstung oder ihre Menschlichkeit anzueignen, bestehen bleibt, nachdem DARK souls diese Option einmal etabliert hat. Und tatsächlich: Man kann nicht nur nahezu jeden NPC töten; obendrein geht dies meist verhältnismäßig mühelos vonstatten, als wollte das Spiel seine Spielerinnen und Spieler daran erinnern, dass es ihnen möglich ist, sich jederzeit ein wenig Erleichterung zu verschaffen, wenn sie nur bereit sind, Fünf gerade sein zu lassen und auch diejenigen umzubringen, die ihnen friedfertig und hilfsbereit oder sogar mit Freundlichkeit begegnen.

Entsprechend schlussfolgert Ascher:

Die prekäre, ständig gefährdete Existenz, in die das Spiel den Avatar durch seinen im wahrsten Sinne des Wortes ,mörderischen' Schwierigkeitsgrad versetzt, gibt dem Spieler ein Gefühl dafür, wie es ist, ein Gejagter zu sein. Doch es macht ihn auch zum Jäger. Wie ein Wolf im Schafspelz wandelt der Avatar unter den NPCs - selbst ausgezehrt, deswegen aber nur umso gefährlicher. Nicht über sie herzufallen erfordert Beherrschung und ist nur durch Empathie möglich, denn erst wenn der Spieler Anteil an dem meist tragischen Schicksal eines NPCs nimmt, kann dieser für ihn mehr als eine Ansammlung begehrenswerter Items sein. ${ }^{89}$

Da kann man nur zustimmen. Wobei der schiere Umstand, dass DARK SOULS den Spieler immer wieder dazu verlocken will, sich am Tod der Wehrlosen zu bereichern, meines Erachtens ausreicht, um die moralische Position des Avatars selbst dann zu erschüttern, wenn man diese Möglichkeit nicht wahrnimmt. Ihre Präsenz suggeriert ja, dass DARK SOULS seinen Spielerinnen und Spielern zutraut, dergleichen zu tun. Und tatsächlich ist es unmöglich, das Spiel zu beenden, ohne sich die Hände schmutzig zu machen. DARK SOULS erlaubt es dem

88 Ascher: Feuerhüterinnen als Kristallisationspunkte des Begehrens. 89 Ascher: Feuerhüterinnen als Kristallisationspunkte des Begehrens. 
Spieler nicht, sich aller Ambivalenzen zu entwinden - zumindest im Fall der Wölfin Sif besteht wenig Zweifel, dass man das Blut einer Gerechten vergießt; und der Zweifel wird immer geringer, je mehr man weiß über die Welt des Spiels.

Schließlich muss noch erwähnt werden, dass der Spieler nicht nur bezogen auf die Nichtspielercharaktere zum Jäger werden kann. Auch andere Spieler eignen sich als Beute. DARK SOULS ist nicht zuletzt berühmt für seinen asynchronen Mehrspielermodus, der es den Spielern erlaubt, einander zu unterstützen oder aber auf die Jagd nach Ihresgleichen zu gehen. In der simpelsten Variante läuft das so ab, dass man einen bestimmten Gegenstand nutzt (den „Cracked Red Eye Orb“), um in der Gestalt eines roten Phantoms die Welt eines anderen Spielers zu invadieren, den man dann zu töten versucht. Gelingt das, erhält der Eindringling als Lohn etwas von den Seelen und der Menschlichkeit seines Opfers. Wichtig ist nun, dass man niemals weiß, in wessen Welt man landen wird. Unternimmt man eine Invasion, bringt DARK SOULS einen Algorithmus zur Anwendung, der Spieler zusammenzuführen sucht, deren „Soul Level“ möglichst nahe beieinander liegt und jedenfalls verhütet, dass zwei Avatare einander begegnen, die in ihren Fähigkeiten zu weit auseinanderliegen. Dennoch ist natürlich unklar, ob der Eindringling auf einen Neuling treffen wird, der noch nie gegen einen anderen Spieler gekämpft hat, oder auf einen Veteranen, der vielleicht schon Dutzende oder gar Hunderte solcher Duelle bestritten hat.

Umgekehrt ist es möglich, mittels des „White Sign Soapstone“ ein Zeichen zu hinterlassen (bevorzugt bei einem Leuchtfeuer am Rande eines besonders schweren Gebiets oder nahe dem Eingang zu der Arena, wo der nächste Boss wartet), das es anderen Spielern erlaubt, den eigenen Avatar in ihre Welt zu rufen. Man erscheint dann als weißes Phantom, um dem jeweiligen Spieler beizustehen. Sollte es gelingen, gemeinsam den Boss des jeweiligen Gebiets zu besiegen, wird der Spieler, der seine Hilfe erbot, mit Menschlichkeit entlohnt. Auch in diesem Fall trifft DARK SOULS gewisse Vorkehrungen, um zu verhindern, dass ein übermächtiger Avatar ratzfatz sämtliche Gegner weit und breit niederhaut - und den Boss erschlägt, als wäre er eine waidwunde Fliege. Und auch in diesem Fall zielt die Mechanik darauf ab, Spieler in der Anonymität einer zufälligen Paarung zusammenzubringen, obgleich es unter bestimmten Voraussetzungen möglich ist, gezielt Freunde in die eigene Welt zu rufen (und mitunter mehr als zwei Spieler gegeneinander antreten oder miteinander kämpfen können).

Wie gesagt - dies sind die basalen Varianten des Mehrspieler-Modus von DARK SOULS. Es gibt allerdings noch zahlreiche andere. Sie eröffnenen sich dem Spieler, wenn er den sogenannten „Covenants“ beitritt, die einem bestimmten NPC oder einer Gottheit unterstehen. Diese Bündnisse, Pakte oder Orden sind auf teils hochkomplexe Weise in die Narration des Spiels eingewoben und verlangen 
von ihren Adepten die Konfrontation in Player-versus-Player-Kämpfen (PvP) oder die Kooperation mit anderen Spielern; wer die Herausforderungen erfolgreich meistert, wird von dem Herrscher oder der Herrscherin des jeweiligen „Covenant“ belohnt, und umso höher fällt die Belohnung aus, je öfter man seine Bündnistreue unter Beweis gestellt hat.

Um einen Eindruck davon zu vermitteln, wie auch diese Mechanik auf die Zeitlichkeiten sich bezieht, die so wesentlich sind für die Spielerfahrung, sei erwähnt, dass es gar nicht leicht ist, gewissen Pakten beizutreten. Häufig ist das deshalb so, weil die Anführer der Bündnisse in verborgenen Winkeln der Spielwelt warten. Wer beispielsweise Mitglied der „Blade of the Dark Moon“ werden will - ein Orden, der Spieler jagt, die sich versündigt haben (etwa als Eindringlinge in die Welten anderer Spieler) -, muss in Anor Londo erst Dark Sun Gwyndolin finden, was unter anderem erfordert, dass man zuvor einen bestimmten Ring entdeckt hat und durchschaut, dass es sich bei einer bestimmten Statue des Sonnenkönigs Gwyn um eine Illusion handelt. Auch hier gibt es also die Mühen einer Zeitlichkeit, die Stasis und Wiederholung gestaltet, bis sie von jener anderen Zeitlichkeit abgelöst wird, die im gebieterischen „Jetzt!“ einer epiphanischen Erkenntnis sich erfüllt.

Um den Mehrspieler-Modus von DARK SOULS in den Details seiner Funktionsweise aufzuschlüsseln, wäre gewiss ein eigener Aufsatz vonnöten. Insbesondere wäre das der geeignete Ort, die Resonanz dieses Modus in den Paratexten des Spiels zu untersuchen. Dass DARK SOULS eine derart herausgehobene Stellung einnimmt, verdankt sich nicht zuletzt dem beinah mythischen Ruch, der vor allem die PvP-Gefechte umwabert: Wer hier besteht, darf sich einer Spielerelite zugehörig fühlen, die den populärkulturellen Nimbus der Marines oder Navy SEALs ins Digitale überträgt.

Für den gegebenen Zusammenhang ist vor allem eines wichtig: Wer als Jäger, nicht nur als potenzielle Beute, in den Mehrspieler-Modus von DARK SOULS einsteigen will, muss eine aktive und bewusste Entscheidung treffen. Zumeist muss man Menschlichkeit konsumieren (was in der Regel eben die Voraussetzung ist, um als Phantom spielen zu können) und dann einen „Cracked Red Eye Orb“ oder den „White Sign Soapstone“ verwenden. ${ }^{90}$ Das ist von besonderer Bedeutung, wenn es um PvP-Kämpfe geht. Anders als in Titeln wie OVERWATCH (Blizzard Entertainment, 2016), FORTNITE (Epic Games/People Can Fly, 2017) oder PLAYERUNKNOWN'S BATTLEGROUNDS (PUBG Cooperation, 2017) ist es in DARK SOULS

90 Eine Ausnahme stellt etwa der „Blue Eye Orb“ der „Darkmoon Blades“ dar, der sich auch als „Hollow“ benutzen lässt. 
nämlich keine selbstverständliche Gegebenheit des Spielprinzips, dass man seinen Mitspielern - sei es im sogenannten „Battle Royale“-Modus, aktuell das Lieblingskind der Spieleindustrie, ${ }^{91}$ oder einer anderen Art des Multiplayer-Kampfes - agonal entgegentritt. Vielmehr muss man in DARK SOULS den Willen aufbringen, einem Mitspieler zu schaden, ihn seiner Menschlichkeit, seiner Seelen und seines Spielfortschritts zu berauben. Man kann das auf faire Weise tun (indem man seinem Opponenten in einem Duell begegnet) oder sich heimtückischer Mittel bedienen (indem man ihn beispielsweise von hinten angreift, während er sich anderer Gegner zu erwehren sucht) - immer aber bleibt das Faktum bestehen, dass man sich eines Übergriffs, einer Transgression oder eben einer „Sünde“ schuldig macht.

Es wird also hinreichend klar, dass der Avatar, wenn er sich auf diesen Pfad begibt, es um den Preis des eigenen Heils tut. Fortan wird er unentwirrbar in den Fluch verstrickt sein, der die Welt von DARK SOULS in Dunkelheit, Verfall und Tod gestürzt hat. Dass die Implikationen ihrer Handlungen vielen Spielern sicher herzlich egal sind, ändert für meine Begriffe nichts an der affektpoetischen Wucht, die dieser Spielmechanik eignet. Vielleicht ist sogar das ein Teil des Kalküls von DARK SOULS. Wie gesagt: Das Spiel gibt sich alle Mühe, die Spielerinnen und Spieler zu Taten zu verführen, bei denen ihnen vielleicht nicht ganz wohl ist; und DARK SOULS tut dies, indem es Sorge trägt, dass diese Taten sich genussvoll erleben lassen. Und das nicht nur wegen der Belohnungen, die den erfolgreichen Invasoren winken, sondern auch und vor allem wegen des ganz besonderen Thrills, den der PvP-Kampf verspricht. Dieser Thrill ergibt sich eben aus den Zeitlichkeiten, die DARK SOULS als Spielerfahrung gestaltet: Es ist die Intensität eines Kampfsystems, das Gegenwärtigkeit produziert, kulminierend im gebieterischen „Jetzt!“ der Entscheidung - eine Intensität, die selbstredend noch einmal gesteigert wird in der Konfrontation mit Gegnern, die keinen vorgezeichneten Angriffs- und Verteidigungsmustern folgen, sondern in jeder Sekunde etwas Unerwartetes tun könnten.

91 Vgl. zur Entstehungs- und Entwicklungsgeschichte dieses Spielmodus: Marcel Kleffmann: Im Wandel der Zeit. Battle Royale. In: www.4players.de, 16. August 2018, http://www.4play ers.de/4players.php/dispbericht/Allgemein/Special/4888/83321/0/Spielkultur.html [letzter Zugriff: 12.05.2020]. 


\section{Ästhetische Lebendigkeit}

$\mathrm{Zu}$ Beginn meiner Überlegungen habe ich die Frage aufgeworfen, warum sich so viele Spielerinnen und Spieler begierig dem Reglement eines Spieles unterwerfen, das auf den ersten Blick ziemlich wenig mit dem zu tun hat, was man gemeinhin unter vergnüglicher Freizeitgestaltung versteht - denn der Schwierigkeitsgrad von DARK SOULS kann ebenso niederdrückend sein wie die Düsternis der Spielwelt und die Trostlosigkeit der Schicksale, die einem auf der Reise durch Lordran, Drangleic oder Lothric begegnen.

Auf den vorangegangenen Seiten habe ich versucht, die das Genre des Action-RPG bestimmenden Spieleraktivitäten des Kämpfens, Erkundens und Nachdenkens in der spezifischen Ausprägung zu analysieren, die ihnen Hidetaka Miyazakis Spieldesign angedeihen lässt. Dabei bin ich immer wieder auf den Umstand gestoßen, dass die verschiedenen Mechaniken - vom Kampfsystem bis hin zur Verwaltung der Ausrüstung - ebenso wie die Architektur und das atmosphärische Gepräge der Spielwelt sowie die Interaktion mit Nichtspielercharakteren präzise zusammenwirken, um ein dynamisches Ineinander spannungsreicher Zeitlichkeiten $\mathrm{zu}$ gestalten. Ich habe diese Zeitlichkeiten unter verschiedenen Aspekten betrachtet und ihnen dabei unterschiedliche Namen gegeben; ganz allgemein kann man vielleicht sagen, dass DARK SOULS eine zyklische Zeit und eine vektorielle Zeit gegeneinander in Stellung bringt, sie zugleich ineinander verschränkt.

Freilich lassen sich die beiden solcherart bestimmten, grundlegenden Zeitlichkeiten in vielfacher Auffaltung genauer erfassen. Von zyklischer Beschaffenheit ist die Zeit der Wiederholung (gleichsam im Rhythmus des Sterbens getaktete Versuche, ein Gebiet zu erkunden oder eine besonders schwierige Stelle zu meistern), die sich zur Zeit des Ausharrens steigern kann (wenn sich etwa ein Boss als scheinbar unüberwindlich erweist; noch die Dauer, die der Lauf vom Leuchtfeuer zum Ort des Kampfes in Anspruch nimmt, ist dann Teil dieser Zeit, beherrscht von den Fragen: Was habe ich falsch gemacht? und Was kann ich besser machen?) und in einer Zeit der Stasis kulminiert (wenn auch der zwanzigste Versuch, den Boss zu besiegen, nicht fruchtet; oder wenn man sich hoffnunglos in einem labyrinthischen Gebiet verlaufen hat und den einen gangbaren Weg nicht findet). Ebenso kann man die vektorielle Zeit in viele verschiedene Varianten von unterschiedlicher Intensität gliedern. Ihnen gemein ist, dass sie auf die Gestaltung von Gegenwärtigkeit abzielen. Es gibt das spannungsvolle Jetzt!, wenn man den Übertritt in ein unbekanntes Gebiet vollzieht und dieses Gebiet dann mit größter Wachsamkeit erkundet; das erleichtert-freudige Jetzt!, wenn man eine Abkürzung findet, die zurück zu einem Leuchtfeuer führt; das triumphale Jetzt!, wenn man einem Boss nach schweißtreibendem 
Kampf den Garaus macht; das ebenso angstvolle wie erregende Jetzt!, wenn ein dumpfer Ton und ein weißer Text auf schwarzem Grund anzeigen, dass ein anderer Spieler, der Übles im Schilde führt, in die eigene Welt eingedrungen ist; und das epiphanische Jetzt!, wenn man meint, etwa aufgrund der Lektüre einer Gegenstandsbeschreibung oder des Auffindens einer bestimmten Leiche an einem bestimmten Ort, eines der zahllosen Geheimnisse von DARK souLS gelüftet zu haben. ${ }^{92}$

Ich habe die genannten Zeitlichkeiten hier aus der Perspektive der Spielerfahrung und bezogen auf die eigenen Handlungsmöglichkeiten beschrieben. Um es noch einmal zu unterstreichen: Jenes Spannungsverhältnis konfligierender Zeitlichkeiten lässt sich bis zu einem gewissen Grad unabhängig von den Spielerinnen und Spielern bestimmen, als objektiver Bestandteil der Spielwelt. Es findet etwa darin seinen Ausdruck, dass in DARK SOULS alles zugleich lebendig und tot erscheint, ohne wirklich eines von beidem zu sein: Das auswegloszyklische Dasein der Untoten und eine eruptive, unbesiegliche Lebendigkeit verbinden sich hier.

Das soll als Resümee genügen. Jedenfalls will ich behaupten, dass sich der Genuss von DARK SOULS vorwiegend der Intensität jener Zeitlichkeitserfahrungen verdankt. Hier nun kommt Alain Badious Konzept einer „Dialektik der Schwärze“ zu ihrem Recht. Wir erinnern uns: Für Badiou vereint die NichtFarbe Schwarz in sich ein Zuviel und ein Zuwenig, einen Mangel und einen Überschuss, die zueinander in einem wechselseitigen Bedingungsverhältnis stehen, ohne ineinander aufzugehen. Es scheint mir offensichtlich, dass die spezifische Schwärze, die DARK SOULS als ästhetische Erfahrung gestaltet, in dieser Dialektik gefasst werden kann. Überall finden wir den Umschlag vom Zuwenig ins Zuviel (und umgekehrt), wobei beide Qualitäten immer wieder nach dem jeweiligen Gegenpol verlangen.

92 In der materialitätstheoretischen Debatte wurde immer wieder das präsentische Jetzt gegen das Hermeneutisch-Prozesshafte, was hinter den Zeichen liegt, in Stellung gebracht. Vgl. etwa: Dieter Mersch: Was sich zeigt. Materialität, Präsens, Ereignis. München 2002; Erika Fischer-Lichte: Ästhetik des Performativen. Frankfurt a. M. 2004; Hans Ulrich Gumbrecht: Plötzlichkeit. Berlin 2012.

Hingegen muss das Präsentische im Videospiel, wie mir scheint, als Teil der ästhetischen Erfahrung adressiert werden, der nicht in einem Entweder-Oder-Verhältnis vom Diegetischen und den auf erlernbaren Spielmechaniken basierenden Aktivitäten des Spielers abgegrenzt werden kann. Vielleicht würde es sich lohnen, die so umrissene Problematik einmal in Ausführlichkeit zu ergründen. An dieser Stelle will ich mich mit dem Hinweis auf zwei Werke begnügen, die u. a. auf eine Kritik der genannten Aporie zielen: Benne: Die Erfindung des Manuskripts; Lötscher: Die Alice-Maschine. 
Anhand des Schwierigkeitsgrads von DARK SOULS lässt sich aufzeigen, was das konkret bedeutet. „From bloodbath to bubble bath“ - die etwas flapsige, aber dennoch sehr präzise Formel, die Jason Killingsworth geprägt hat, umreißt die Bewegung, welche die Spielerinnen und Spieler im Laufe vieler Stunden vollziehen: Was unerträglich schwer schien, wird ganz leicht, allzu leicht, sodass manch ein Aficionado alles tut, um die Mühen des Anfangs, mithin auch die Intensität des Triumphs, wiederherzustellen, beispielsweise über den gezielten Verzicht auf bestimmte Hilfsmittel, oder indem er sich bis zum NG +3 oder NG + 4 vorarbeitet, wo das Vertraute von Neuem fremd und gefährlich wird. Freilich hören die Spielwelt, die Mechaniken, die Angriffs- und Verteidigungsmuster der Gegner dabei nicht auf, vertraut zu sein. Wären die verworrensten Wege nicht längst schon Heimat, die fremdartigsten und gefährlichsten Gegner nicht längst schon alte Bekannte - kein Spieler hätte eine Chance, in Anbetracht des nochmals intensivierten Schwierigkeitsgrades zu bestehen.

Doch Badiou behauptet ja auch, dass sich die Dialektik der Schwärze in einer spezifischen Wissensordnung ausdrückt; eine Wissensordnung, die DARK souls gestaltet und in der Spielerfahrung zu einer Wirklichkeit der Spielerinnen und Spieler werden lässt, die deren Denken und Fühlen bestimmt, inwiefern und insoweit sie ihr eigenes Sein mit dem ästhetischen Entwurf von Hidetaka Miyazaki kurzschließen; eine Wissensordnung, deren abgründige Grausamkeit sich zurückführen ließe auf eine Poetik in der Tradition de Sades. Vielleicht könnte man sagen, dass das Wissen in dieser Perspektive stets droht, sich selbst zu zerstören, seine eigenen Grundlagen sich zu entziehen, indem es immer nur mehr Schwärze erzeugt, sodass, was sehend machen sollte, allein die Blindheit des Abgrunds zeigt, worin der wahre Grund der Wahrheit zu suchen ist. Ich will diese Überlegungen nicht als Lebensweisheit verstehen, sondern auf eine ästhetische Konfiguration beziehen. Dann erweist es sich, dass DARK SOULS auch in dieser Hinsicht ganz durchdrungen ist von der Dialektik der Schwärze.

Franziska Ascher drückt es sehr treffend aus:

Wenn der Aufbau der Spielwelt, wie zu Beginn postuliert, vertikal ist, so ist die Hauptrichtung im Spiel abwärts und je tiefer der Spieler in die Spielwelt eindringt, desto tiefer dringt er auch in ihre Geheimnisse ein - und desto schwerer lastet die Schuld auf den Schultern des Avatars. Denn Wissen gibt es nur um den Preis der Schuld, obwohl der Spieler nur selten die Wahl hat, einen Bossgegner nicht zu bekämpfen. ${ }^{93}$

Anfangs meint man, die Welt von DARK SOULS verweigere sich jeglichem Bemühen, das auf die Ergründung ihres inneren Zusammenhangs zielt - derart hermetisch

93 Ascher: Die Narration der Dinge Teil II. 
und rätselhaft ist sie. Doch nach und nach treten Ahnungen und Gewissheiten, oder vermeintliche Gewissheiten, an die Stelle der Verständnislosigkeit. Alles, was die Spielerinnen und Spieler herausfinden, vergrößert aber letztlich ein Unwissen zweiten Grades: Wie ist es möglich, dass der Avatar, die Nichtspielercharaktere, die Gegner und Bosse, ja die ganze Spielwelt so heillos in eine fluchhafte Entropie verstrickt sind, die nur in die Schwärze und den Tod zu führen scheint? Das Spielende gibt keine Antworten, sondern führt, im Überschuss des Wissens um jene Fluchhaftigkeit, das immer vor allem eine Erfahrung und ein Gefühl ist, wieder zurück an den Nullpunkt des Un-Wissens. Indessen vollzieht sich noch dieser Prozess, so trostlos die Narration anmuten mag, in dem ästhetischen Genuss jener dynamischen, konflikthaften Zeitlichkeiten, die ich aufzuschlüsseln versucht habe: Denn er findet nicht als Informationsverarbeitung statt, sondern ist eingestaltet in die Spielmechaniken und die Spieleraktivitäten.

So würde ich also sagen, dass die Dialektik der Schwärze ein Bewegungsgesetz bestimmt, das alle Spielmechaniken umfasst; es strukturiert die Aneignung der Welt von DARK SOULS in ihrer affektiven Gerichtetheit, wobei das Ineinander von Zuviel und Zuwenig als Abfolge dynamisch-konflikthafter Zeitlichkeiten ein Gefühl von ästhetischer Lebendigkeit hevorbringt, das alle Mühen des Kämpfens und Erkundens, alle Düsternis der Erzählung, alle Heillosigkeit der Verstrickung des Avatars in sich hineinzieht, umgestaltet und in der Spielerfahrung letztlich überschreitet. Aufgrund der Vielheit an Zeitlichkeiten, die es zu gestalten weiß, ist DARK SOULS also kurioserweise eines der lebhaftesten und, erfahrungsästhetisch gesprochen, buntesten Spiele überhaupt. Es lässt die Dunkelheit erstrahlen, bringt die Schwärze zum Leuchten.

\section{Kompromissbildungen}

Es mag sein, dass meine Antwort auf die Frage, was das rätselhafte Faszinosum von DARK SOULS ausmacht, unbefriedigend erscheint. Vielleicht ist sie zu formalistisch? Mithin ahistorisch und unpolitisch? Der Einwand scheint mir insofern berechtigt, als der Erfolg so merkwürdiger ästhetischer Gebilde, wie es die Spiele von Hidetaka Miyazaki sind - die sich zudem weder einem gegebenen Trend noch einer Mode anschließen, sondern einen Trend und eine Mode begründet haben $^{94}$-, in der Tat nicht nur über intrinsische Qualitäten erklärt werden kann.

94 Vgl. Rudolf Thomas Inderst/Pascal Wagner/Christof Zurschmitten: Einleitung. In: dies. (Hg.): Prepare to die! DEMON SOULS, DARK SOULS und BLOODBORNE. Glückstadt 2019, S. 7-13, hier: S. 7. 
Ich will also zum Schluss einige Überlegungen anstellen, die versuchen, DARK souls auf die Geschichtlichkeit unserer Zeit zu beziehen.

In der Forschung ist dergleichen bereits unternommen worden. Die vorhandenen Ansätze zielen auf den Mehrspieler-Modus, was vielleicht nicht überrascht, da die Branche ja schon seit manchem Jahr darauf setzt, die Spielerinnen und Spieler online im bevorzugt martialischen Wettkampf gegeneinander antreten zu lassen; eine Entwicklung, die immer noch weiter sich verstärkt, was seinen Niederschlag im Raunen vom „Ende der Singleplayer-Spiele“ findet. Abgesehen davon ist es in der Tat eine sehr relevante Frage, welcher Art die virtuellen Gemeinschaften sind, die Spiele wie die bereits erwähnten Titel oder APEX LEGENDS (Respawn Entertaiment, 2019) enstehen lassen - umfassen diese Gemeinschaften doch potenziell Millionen von Menschen, die den unterschiedlichsten sozialen und kulturellen Milieus entstammen und in allen Winkeln der Erde beheimatet sind. Man könnte also sagen, dass die großen Multiplayer-Titel vermittels (ausgerechnet) der Simualtion von kriegerischen Konflikten, von polygonalem Mord und Totschlag sowie digitaler Menschenjagd, vieles verbinden, was sonst getrennt bleibt.

Wie verhält es sich diesbezüglich in DARK SOULs? Tom van Nuenen bringt den Thrill der PvP-Kämpfe mit Foucaults Konzept des „Panopticon“ in Verbindung, das sich herleitet von Jeremy Benthams architektonischen Entwürfen für Gefängnisse, Fabriken und andere Anstalten, in denen die Überwachung vieler durch Einzelne auf der Tagesordnung steht. Somit ist das Panopticon:

the ultimate realization of the modern disciplinary institution and a metaphor for modern disciplinary societies and their inclination to observe and normalize. The Panopticon was specifically designed so that prisoners could never be sure whether they were being watched at any moment. This „unequal gaze“ - the constant possibility of observation creates a consciousness of permanent visibility as a form of power, where no bars, chains, and heavy locks are necessary for domination any longer. Instead, inmates internalize the gaze and the institutional discourse that it represents and start to self-monitor their own behavior. ${ }^{95}$

In van Nuenens Augen ist ein derartiges Blickregime in der ästhetischen Organisation der PvP-Kämpfe von DARK SOULS am Werk. Wobei hier das Spiel selbst, als „an abstracted procedural system“, an die Stelle der Gefängniswächter getreten sei; es sieht und überwacht die Spieler und bestimmt, wer gegen wen an-

95 van Nuenen: Playing the Panopticon, S. 513-514. Vgl. Michel Foucault: Überwachen und Strafen. Die Geburt des Gefängnisses [1975]. Frankfurt a. M. 1992, S. 260: „Derjenige, welcher der Sichtbarkeit unterworfen ist und dies weiß, übernimmt die Zwangsmittel der Macht und spielt sie gegen sich selber aus; er internalisiert das Machtverhältnis, in welchem er gleichzeitig beide Rollen spielt; er wird zum Prinzip seiner eigenen Unterwerfung.“ 
zutreten hat, ${ }^{96}$ etabliert also einen ,post-Panoptic procedural gaze“.${ }^{97}$ Um den Genuss, den der Multiplayer-Modus von DARK SOULS verschafft, in Gänze zu verstehen, muss man Foucaults Ansatz, so van Nuenen, jedoch um Konzepte ergänzen, die darauf zielen, die Funktionsweise von Überwachungspolitiken in der „Cam era“ zu analysieren. Der Begriff ist den Schriften von Hille Koskela entnommen, die der allgegenwärtigen Selbstüberwachung, welcher sich unzählige Menschen mittels Smartphones, Webcams, Reality-TV und Social Media unterwerfen, durchaus emanzipatorische Aspekte abgewinnen kann: „People play a more active role in the production of images than ever before - and being seen, Koskela emphasizes, does not always mean being less powerful. [...] it is an empowered exhibitionism in which continuous visibility is met with enthusiasm.“98

Man könnte also behaupten, dass DARK souls die Angst und die Anspannung, die daher rühren, sich im Panoptikon einem unsichtbaren Blick ausgesetzt zu wissen, mit dem lustvollen Exhibitionismus der „Cam era“ verbinde. So sieht es zumindest van Nuenen.

Er schreibt:

Although the Panopticon was thought up as an ultimate prison system that would keep the prisoner from committing any criminal offences, DARK SOULS is designed for me to do just the opposite - offending, occupying the other's domain. As a result, in later play sessions the fear I initially felt is replaced by cognitive dissonance. There is hesitance, as I do not know who I might be invading next. There is carefulness, as I know my own progress might be hindered by invasion at all times (and losing the battle will mean losing all of my acquired souls). Yet there is also eagerness to push onward, show off, and defeat others. There is excitement over the play of online visibility. DARK SOULS adopts the anxieties of the subject in the Panopticon while adding the playful enthusiasm from the postPanoptic cam-era. Instead of becoming obedient, my incarceration through playing is set up specifically so that I may time and again prove myself in battle. ${ }^{99}$

Wenn das zutrifft, dient der Mehrspieler-Modus von DARK SOULS einer Kompromissbildung. Sie gründet sich darin, jenes Unbehagen, das uns netizens angesichts der allseitig betriebenen und von uns mit Eifer geförderten Auslöschung eines idealiter unverfügbaren Persönlichkeitsbereichs befallen mag, zwar aufzugreifen, dann

96 van Nuenen: Playing the Panopticon, S. 519.

97 Vgl. van Nuenen: Playing the Panopticon, S. 522.

98 van Nuenen: Playing the Panopticon, S. 514-515. Vgl. Hille Koskela: „Cam era“. The Contemporary Urban Panopticon. Surveillance and Society 1 (2003), H. 3 S. 292-313.

99 van Nuenen: Playing the Panopticon, S. 520. 
jedoch in eine lustvolle Selbstbehauptung zu transformieren. ${ }^{100}$ Wir sind nicht in der Lage - so die Logik jener Umkehrung - das Überwachungsregime als solches zu bekämpfen (allerdings lässt es sich, was DARK SOULS anbelangt, buchstäblich ausschalten, indem man offline spielt); wohl aber können wir lernen, uns zu einem besonders effektiven Agenten des Regimes zu machen, dessen Souveränität sich darin erweist, dass er andere, weniger effektive Agenten in „a cathartic confrontation“ mit zunehmender Sicherheit ausschaltet. ${ }^{101}$

Noch einen Schritt weiter geht Elena Bertozzi. Sie untersucht, so der Untertitel ihres einschlägigen Essays, „Pleasures and Potentialities of Predation Play“, widmet sich mithin der Frage, wie die Gewaltausübung in Spielen zu bewerten sei, bei denen das Ziel ist, möglichst viele Gegner, seien sie von anderen Spielern oder vom Computer gesteuert, zu erschießen - beziehungsweise sich selbst nicht erschießen zu lassen. Dabei löst sie sich von der Frage nach Repräsentationsverhältnissen; es geht ihr also nicht darum, ob die Gewalt in den betreffenden Spielen etwa realistisch oder überzeichnet dargestellt ist. Stattdessen beharrt Bertozzi darauf, dass die Bewertung eines Spiels an die Analyse der Kernaktivitäten oder Ideologien geknüpft sein müsse, „that are encouraged, reinforced, and developed during gameplay“. ${ }^{102}$

Was das bedeutet, erläutert sie am Beispiel eines Sports, der nicht unbedingt im Ruf steht, zur Verrohung der Menschheit beizutragen:

Consider what is being played in the game of tennis: the player's capacities to perceive objects flying through space, to intersect their trajectory with another object (the racket),

100 Man könnte in diesen Überlegungen eine Schrumpfform des Ansatzes von de Certeau erkennen, der in seiner Auseinandersetzung mit der brasilianischen Volkskultur schreibt: „Ganz allgemein gesagt, eine Umgangsweise mit aufgezwungenen Systemen führt zum Widerstand gegen das historische Gesetz eines tatsächlichen Zustandes und gegen seine dogmatische Legitimation. Die Benutzung einer von anderen geschaffenen Ordnung führt zu einer Neuaufteilung des Raumes in dieser Ordnung; sie schafft zumindest einen Spielraum für die Bewegungen von ungleichen Kräften und für utopische Bezugspunkte. [...] Tausend Arten und Weisen, das Spiel des Anderen, d. h. den von Anderen vorgegebenen Raum, zu spielen/zu vereiteln, sind charakteristisch für die subtile, beharrliche und widerstandsfähige Aktivität von Gruppen, die sich - da sie kein eigenes haben - im Netz der etablierten Kräfte und Vorstellungen zurechtfinden müssen. Man muß ,mitmachen, indem man etwas damit macht'. In diesen Kriegslisten gibt es so etwas wie die Kunst, einen Coup zu landen, gewissermaßen ein Vergnügen daran, die Regeln einer aufgezwungenen Umwelt auf den Kopf zu stellen. Eine taktische und fröhliche Fingerfertigkeit im Umgang mit einer Technik.“ Michel de Certeau: Kunst des Handelns [1980]. Berlin 1988, S. 59-60.

101 Vgl. van Nuenen: Playing the Panopticon, S. 523-524.

102 Elena Bertozzi: The Feeling of Being Hunted. Pleasures and Potentialites of Predation Play. In: Games and Culture 9 (2014), H. 6, S. 429-441, hier: S. 430. 
and to successfully reverse the trajectory of the flying object to a location on the other side of the net that is difficult for the opponent to reach. The game requires and exercises specific kinds of physical competence and mental discipline and requires players to understand and analyze their opponents' behavior. Criticizing the game of tennis because it is a violent activity that encourages people to hit things very hard and with great precision would not make much sense even though it is true. ${ }^{103}$

Diese Argumentation hat sicherlich etwas für sich. Wie aber verhält es sich in Hinblick auf die Gewalt in Videospielen? ${ }^{104}$ Welche Ideologien werden in ,predation games“ wie DARK SOULS eingeübt? Zunächst einmal geht es darum „the ability to survive in competitive, predatory environments“ zu trainieren. ${ }^{105}$ Darüber hinaus halten derartige Spiele einige grundlegende machtpolitische Lektionen bereit: „Predation play makes power relations overt and malleable; those who engage in it learn the ways power shifts and how to acquire and maintain it. “106 Wie genau geht das zu?

Bertozzi erläutert:

The core ideologies include the following: training the player to succeed in high-stakes competitive environments by increasing situational intelligence and strategic thinking, subjecting the player to objective assessments and the experience of failure, and requiring the player to engage with morally complex situations. Challenging predation games can make players savvier at assessing and calculating opportunities in given environments, more willing to face difficult challenges, and able to learn from failure rather than be crushed by it. Another important aspect of predation games is negotiating collaboration with others and accurately assessing their reliability and utility. ${ }^{107}$

103 Bertozzi: The Feeling of Being Hunted, S. 430.

$104 \mathrm{Im}$ folgenden Kapitel werde ich mich ausführlich mit dieser Frage befassen.

105 Bertozzi: The Feeling of Being Hunted, S. 430. Übrigens ist die Trennlinie zwischen dem Genre der Shooter und den „predation games“ in Bertozzis Analyse sehr unscharf gezogen. $\mathrm{Zu}$ dieser Unschärfe gehört auch, dass die konkreten Spielmechaniken etwa von DARK SOULS wenig präzise beschrieben werden. Tatsächlich kann man den Eindruck bekommen, Bertozzi habe sich niemals selbst mit den Spielen beschäftigt, über die sie schreibt. Jedenfalls ist die folgende Aussage zu DARK SOULS schlicht falsch: „Players can play for long periods of time and make it almost all the way through the first of the game's seven levels (a minimum investment of 30-50 hr). If they die before the end, they lose everything and have to start over again from the beginning." Bertozzi: The Feeling of Being Hunted, S. 434.

106 Bertozzi: The Feeling of Being Hunted, S. 434.

107 Bertozzi: The Feeling of Being Hunted, S. 430-431. Man könnte meinen, dass der von Bertozzi angestellte Tennis-Vergleich ihre eigene Argumentation zumindest teilweise widerlegt: Müssen Spielerinnen und Spieler, die sich etwa mit einem Multiplayer Online-Shooter vergnügen, wirklich „morally complex situations“ konfrontieren, oder wird jeder Ansatz zu einer wie immer gearteten moralischen Situierung zunächst einmal völlig zugunsten der sportlichen (Team-)Erfahrung ausgeklammert? 
Mir scheint, dass dieser Ansatz - den Bertozzi später sozial- und evolutionspsychologisch zu begründen sucht - zwei widerstreitende Bestrebungen zu vereinen sucht. Ihre Ausführungen lesen sich, als würde man ein Trainingscamp für neoliberale Überlebensstrategien betreten, wenn man „predation games“ spielt. Offenbar geht es darum, sich selbst in Hinblick auf Leistung und Effizienz zu optimieren, wozu natürlich auch gehört, das Nützlichkeits- und Bedrohungspotenzial seiner Mitmenschen zu taxieren, die in dieser Sichtweise eigentlich nur als Konkurrenten oder Steigbügelhalter in Betracht kommen. Andererseits möchte Bertozzi in der Raubtierschulung ein gewisses subversives oder aufrührerisches Potenzial erkennen. Immerhin lehren uns Spiele wie DARK SouLS, dass die Machtverhältnisse nicht vom Himmel gefallen, sondern vielmehr hausgemacht sind, sich also durchaus herausfordern und ändern lassen.

Vielleicht zeigen sich in der Widersprüchlichkeit von Bertozzis Ausführungen die Grenzen des auch von van Nuenen bemühten Desiderats „Empowerment“. In der Praxis läuft selbiges ja darauf hinaus, dass die vormals Unterdrückten den Platz der Unterdrücker einnehmen; das heißt, um in der Bildwelt der „predation games“ zu bleiben, sie rutschen in der Nahrungskette ein Stück weit nach oben, ohne dass sich an der grundsätzlichen Logik des Fressens und Gefressen-Werdens etwas ändern würde. Damit legen van Nuenen und Bertozzi, was immer ihre Absichten gewesen sein mögen, eine Aporie (oder, weniger technisch ausgedrückt, einen Schmerz und eine Verzweiflung) unserer Zeit offen. Auf einen Gewinner kommen zehntausend Verlierer. Jeder weiß das, und jeder lebt damit - solange er nicht selbst auf der falschen Seite der Zäune und Mauern sich wiederfindet.

Was heißt das nun bezogen auf DARK SOULs? Es lässt sich wohl nicht leugnen, dass ein agonaler, asymmetrischer Mehrspieler-Modus, wie ihn Miyazaki und seine Mitarbeiter entwickelt haben, ein Stück weit den allgegenwärtigen (Selbst-)Verwertungs- und Optimierungslogiken sich andient, mit denen uns der wildgewordene Kapitalismus unserer Tage (wenn es je einen anderen gab) rund um die Uhr traktiert. Mag sein, dass der PvP-Enthusiasmus der Spieleindustrie insgesamt eine Ursache in diesem Zusammenhang hat. Demgegenüber könnte man sagen - mit van Nuenen und vielleicht auch mit Bertozzi -, dass die Spielerinnen und Spieler in den Mehrspieler-Gefechten verschiedenster Art eine Möglichkeit finden, den unerträglichen Konkurrenz- und Leistungsdruck, welcher ihnen von einer unentrinnbaren Wirklichkeit auferlegt wird, spielend $\mathrm{zu}$ genießen und sich so ein wenig Luft $\mathrm{zu}$ verschaffen. Zumal es ja meist eine andere Seite gibt: das Miteinander, die wechselseitige Unterstützung im Meistern der Herausforderungen. Der Ritter Solaire of Astora, dem man recht früh in DARK SOULS begegnet, nennt das „jolly co-operation“. Er ist wohl 
nicht zufällig der beste Freund des Spielers, der bei weitem beliebteste NPC und vielleicht sogar der wahre Held von Lordran. ${ }^{108}$

\section{Die Zeitlichkeit der Assemblage}

In Hinblick auf Hidetaka Miyazakis Spiel scheint es mir allerdings angebracht, noch einen weiteren Aspekt $\mathrm{zu}$ bedenken. Meine bisherigen Ausführungen mögen verdeutlicht haben, dass DARK SOULS den Fantasy-Modus einer paradoxen Vollendung zuführt. Das gilt für ihre mythopoetische Neigung, Welten aus Geschichten zu bauen, die, wenn man sie ergründet, eine Ahnung neuer Geschichten preisgeben, sodass der Genuss eines potenziell unbegrenzten Abenteuerraums lockt. DARK SOULS frustriert dieses Prinzip, und erfüllt es dabei zugleich (oder umgekehrt). Die Spielwelt ist von geheimnisvoller Rätselhaftigkeit, deutet eine Vielzahl ineinander verwobener Schicksale und Historien an, ohne je zu offenbaren, was wirklich geschehen ist, sodass man leicht das Gefühl bekommen kann, es sei unmöglich, die raumzeitlichen Tiefen von Lordran (oder Drangleic oder Lothric) auszuloten - ganz gleich, wie oft man das Spiel beendet. Es gilt desgleichen für den Umstand, dass die Welten der Fantasy stets einem Gesetz von Gut und Böse unterstehen. Hier erlaubt sich DARK SOULS eine besonders kühne Ausdeutung: Denn obgleich die Valenzen von Licht und Dunkelheit hier bis zur Heillosigkeit verdreht, verwirrt und vertauscht werden, lässt das Spiel doch stets erahnen, dass es Gut und Böse gibt, irgendwo, außerhalb der Reichweite und des Fassungsvermögens all der elenden Kreaturen, die das verfluchte Königreich durchstreifen. Das betrifft insbesondere die ästhetische Erfahrung der kleinen Dinge: Welcher Spieler wollte bestreiten, dass ein Leuchtfeuer, durchaus in einem metaphysischen Sinn, gut ist? Darüber hinaus gilt es, vielleicht überraschend, auch für das affektpoetische Prinzip, das die Denkfigur der „Eukatastrophe“ in sich birgt. Tatsächlich besteht DARK SOULS aus einer Folge von unzähligen Eukatastrophen. Wie oft erscheint ein Boss bei der ersten Begegnung völlig unbesiegbar? Doch stets aufs Neue flackert Hoffnung

108 Keza MacDonald und Jason Killingsworth schreiben über ihn: „He gifts you the White Sign Soapstone in your earliest encounter, which allows you to summon the help of others beside him. He is the model of teamwork and persistence in the face of terrible odds. In this way he becomes a role model, quite literally DARK Souls leading light.“ Keza MacDonald/Jason Killingsworth: Character-Building. Meet the Cast of DARK SOULS. In: dies.: (Hg.): You Died, S. 298-327, hier S. 302. Übrigens ist Solaire einer der wenigen Nichtspielercharaktere, die man tatsächlich vor einem bitteren Los bewahren kann. 
auf, dass es anders sein könnte. Irgendwann schließlich fällt der Gegner, obgleich sich der Sieg gegen jede Wahrscheinlichkeit ereignet. Und ist nicht jede Abkürzung, jedes Leuchtfeuer, jedes überstandene Drangsal eine Eukatastrophe in diesem Spiel? Auf seltsame Art erfüllt sich dieses Prinzip sogar noch in der zyklischen Zeitlichkeit, welche die Welt von DARK SOULS gefangen hält: Denn obgleich das Ende des Spiels als solches wenig Anlass zur Hoffnung gibt, besteht die Eukatastrophe darin, dass der Avatar immer weiter macht, niemals aufgibt vielleicht kein glücklicher, aber ein überaus hartnäckiger Sisyphos.

Wenn all das zutrifft, muss auch gelten, dass DARK SOULS die Sehnsucht nach dem ganz Anderen kennt. Denn dieses Gefühl lebt mehr als jedes andere im Herzen der Fantasy - haben wir es hier doch mit einem Genre zu tun, das sich den Traum von einer besseren Welt, sei er noch so naiv und kitschig, nicht austreiben lässt. Tatsächlich hoffe ich, gezeigt zu haben, dass DARK SOULS in vielerlei Hinsicht ein von Sehnsucht erfülltes Spiel ist.

Es gibt aber eine in das Spiel eingestaltete Figuration, über die ich bislang noch nicht gesprochen habe. Indessen erlaubt sie es, DARK SOULS in anderer Weise auf die Historizität unserer Gegenwart zu beziehen. Ich rede von der Assemblage. Im sogenannt posthumanistischen oder - vielleicht treffender neomaterialistischen Feminismus ${ }^{109}$ bezeichnet die Assemblage eine Ansammlung heterogener Entitäten und Materialien. Gemäß Anna Lowenhaupt Tsing verbinden sich in ihr Menschen, Tiere, Pflanzen, Maschinen und Dinge, wobei entscheidend ist, dass die Assemblage keinem hierarchischen Ordnungsprinzip folgt; sie strebt nicht danach all das Heterogene, was in ihr sich berührt, im Vollzug einer vorab festgelegten Logik stillzustellen. ${ }^{110}$ Im Gegenteil, laut Lowenhaupt Tsing sind Assemblagen stets produktiv und in ihrer Produktivität der unausgesetzten Wandlung verpflichtet: ,assemblages don’t just gather lifeways; they make them." ${ }^{111}$ Was das konkret bedeutet, zeigt Lowenhaupt Tsing

109 Wie so oft, wenn eine Bewegung heraufbeschworen wird, widersetzen sich manche ihrer vorgeblichen Protagonistinnen und Protagonisten dem Etikett, das ihre Arbeit subsumieren soll. Während sich Rosi Braidotti affirmativ auf posthumanistische Konzepte bezieht und Anna Lowenhaupt Tsing die einschlägige Begrifflichkeit überhaupt nicht verwendet, grenzt sich Donna J. Haraway explizit vom Posthumanismus ab: „Companion species are relentlessly becoming-with. The category companion species helps me refuse human exceptionalism without invoking posthumanism. “ Donna J. Haraway: Staying with the Trouble. On Making Kin in the Chthulucene. Durham/London 2016, S. 13. Gemeinsam ist den genannten Denkerinnen, dass sie eine Vorherrschaft des Menschen, wie sie im „Phallogozentrismus“ präfiguriert ist, zu überwinden suchen.

$110 \mathrm{Vgl}$. Anna Lowenhaupt Tsing: The Mushroom at the End of the World. On the Possibility of Life in Capitalist Ruins. Princeton/Oxford 2015, S. 23.

111 Lowenhaupt Tsing: The Mushroom at the End of the World, S. 23. 
unter anderem am Beispiel des überaus wertvollen Matsutake-Pilzes, der in von Menschen abgeholzten und vergifteten Wäldern wächst und um den herum dynamische Biosphären sich herausbilden, in denen jedes einzelne Element alle anderen beeinflusst, woraus ungeahnte Wachstumspotenziale entstehen, die vielstimmigen, ungerichteten Rhythmen folgen: ,a gathering that's greater than the sum of its parts ${ }^{112}$ Hier verbinden sich Natur und Kultur, und auf den verschlungenen Pfaden von Kontamination und Kollaboration entwickelt sich Neues aus den Trümmern des Kapitalismus.

Lowenhaupt Tsing versteht die Assemblage jedoch nicht nur als faszinierendes Öko-Phänomen. Vielmehr soll sie Denkprinzipien stiften, die neue Betrachtungsweisen von politischen, ökonomischen und historischen Prozessen erlauben. Christine Lötscher beschreibt diesen Zusammenhang wie folgt:

\begin{abstract}
Vor dem Hintergrund eines Kapitalismus, der elaborierte Techniken, oder eben Maschinen, entwickelt hat, um alles in Ressourcen zu verwandeln, ganz egal ob Mensch, Tier, Pflanze oder Ding, werden hier Denkansätze entwickelt, um dieser Kampf- und Verwertungslogik zu entkommen und eine andere Perspektive auf die Welt zu gewinnen. Lowenhaupt Tsing arbeitet heraus, wie der Kapitalismus, um in Maschinen, Unternehmen, Ideen, Menschen investieren zu können, alles von allem trennen - marxistisch gesagt: entfremden - muss. Denn wenn alles für sich allein steht, verschwinden die Verwicklungen lebendiger Materie aus dem Sichtfeld, das ganz darauf fixiert ist, die artifiziellen Grenzziehungen zu naturalisieren. ${ }^{113}$
\end{abstract}

Es geht also darum, den artifiziellen Grenzziehungen zu entraten, das heißt, ein Denken zu fördern, welches nicht an Dichotomien oder identitären Zuschreibungen orientiert ist, was etwa auch die ontologischen Trennlinien zwischen Mensch und Tier, Kultur und Natur beträfe. Die Implikationen eines solchen Projekts sind sehr weitreichend; tiefgreifende Veränderungen wären nötig, um selbst kleinere Schritte auf diesem Weg zu ermöglichen.

Fest steht, dass die Prinzipien eines Denkens der Assemblage für die Analyse ästhetischer Kompositionen produktiv sein können. Das wird an DARK souls deutlich. Wobei ich allerdings keine Revision meiner Thesen anstrebe; sie behalten, so meine ich, ihre Gültigkeit. Sogar die Dialektik der Schwärze als allgemeines Bewegungsgesetz bleibt bestehen - obgleich Lowenhaupt Tsing und Lötscher die Voraussetzungen des Badiouschen Ansatzes infrage stellen würden, da Kategorien wie Mangel und Exzess aus ihrer Sicht der dichotomischen Erstarrung verfallen sind. Was sich vor allem ändert, wenn Hidetaka Miyazakis Spiel durch das Prisma der Assemblage betrachtet wird,

112 Vgl. Lowenhaupt Tsing: The Mushroom at the End of the World, S. 23. 113 Lötscher: Die Alice-Maschine. 
ist der Blickwinkel. Die Assemblage erlaubt es, die Welt von DARK SOULS sozusagen mit neuen Augen $\mathrm{zu}$ betrachten. Dann fällt auf, dass hier zahllose Räume und Wesenheiten gestaltet sind, die sich durch mannigfaltige und überraschende Kombinationen von Menschlichem und Tierischem, Organischem und Anorganischem, Lebendem und Totem, Naturhaftem und Mechanischem auszeichnen. Vielleicht verspüren viele Spielerinnen und Spieler eine Sehnsucht danach, in einer solchen Welt zu verweilen, Teil von ihr zu sein. Dass dies nicht wirklich möglich ist, wäre eine Konsequenz des historischen Ortes, den DARK souls einnimmt: Das Spiel kann eine Welt, die artifizielle Grenzziehungen auflöst, zwar gestalten, nicht aber bewohnbar machen. Immer bleibt das Verhältnis des Avatars - und mithin der Spielerinnen und Spieler - zu ihr von Kampf, Leid und Sterben geprägt.

Doch aus Sicht der Assemblage lässt sich noch die zyklische Zeit des fortwährenden Vergehens und Entstehens anders versteht: weniger als höllische Ausweglosigkeit, denn als Sehnsucht, eingeborgen $\mathrm{zu}$ sein in eine Welt, wo nicht nur das Humane und Ahumane, nicht nur das Organische und Anorganische verschmelzen, sondern auch Tod und Leben ineinander übergehen, in dem Sinn, wie Rosi Braidotti fordert, Schluss zu machen mit der ,Überbewertung des Todes‘: „Die letztendliche Subtraktion ist schließlich nur eine neue Phase in einem generativen Prozess. “114 Für die Spielerfahrung, die DARK SOULS ermöglicht, trifft das allemal zu. Immerhin erhält der Tod selbst hier die Signatur ästhetischer Lebendigkeit.

Ebenso kann man vor diesem Hintergrund die Obsession des Spiels mit den Insignien des Gothic - Ruinen, Nebel, Düsternis und allgegenwärtiger Verfall einer Umdeutung unterziehen. Nicht als wohliges Schwelgen in überkommenen Kunstformen oder schlicht als Rückgriff auf atmosphärische Stereotypen muss man jene Obsession dann begreifen; vielmehr als Ausdruck des Bemühens, eine bestimmte Idee von Zeit zu gestalten, in der sich die unauflösliche Verbundenheit von Werden und Vergehen einschreibt. Mit John Ruskin, der den Gothic als eine Assemblage avant la lettre definiert, ${ }^{115}$ könnte man sagen: „Nothing that lives is, or can be, rigidly perfect; part of it is decaying, part nascent. “116

114 Rosi Braidotti: Politik der Affirmation. Berlin 2018, S. 40.

115 Lars Spuybroek hat bereits aufgezeigt, inwiefern Ruskins Gothic-Konzeption das digitale Denken präfiguriert. Vgl. Lars Spuybroek: The Sympathy of Things. Ruskin and the Ecology of Design. London 2016.

116 John Ruskin: The Nature of Gothic. In: ders.: The Works of John Ruskin. Vol. 10: The Stones of Venice. Volume II. London 1904, S. 203. Zitiert nach: https://babel.hathitrust.org/cgi/pt?id= osu.32435018887133\&view=1up\&seq=7 [letzter Zugriff: 12.05.2020]. 
Oder um eine ebenso berühmte wie enigmatische Liedzeile Bob Dylans zu paraphrasieren: Wer DARK SOULS spielt, ist im selben Moment damit beschäftigt, geboren zu werden, und zu sterben. ${ }^{117}$

Möglicherweise wäre dies auch ein Hinweis darauf, wo jene „incredible power to create communities out of shared hardship“ herrührt, ${ }^{118}$ die für Keza MacDonald das Herz der Spielerfahrung von DARK SOULS bildet. Verbinden sich in ihr doch, wie MacDonald schreibt, die beiden gegenläufigen Gefühle „of being simultaneously entirely alone and part of a brethren of lone adventurers“. ${ }^{119}$ Hidetaka Miyazakis Trilogie erzeugt diese Gefühle, indem sie - aufgrund der unergründlichen Rätselhaftigkeit ihres Weltbaus ebenso wie ihres berüchtigten Schwierigkeitsgrades - eine potenziell unabschließbare Produktion von Paratexten anregt (in Gestalt von Foren, Wikis und YouTube-Videos), die wohl nahezu jeder Spieler früher oder später zu Rate ziehen wird, wodurch sich seine Mühen und seine Freuden mit den entsprechenden Erfahrungen buchstäblich zahlloser Fremder verbinden.

DARK SOULS stiftet derartige Verbindungen aber desgleichen im Spiel selbst, auch jenseits der Möglichkeiten zu PvP-Kämpfen und ,jolly co-operation“; dies geschieht mithilfe einiger Mechaniken, die (zumindest im Online-Modus) die Spielerinnen und Spieler immer wieder daran erinnern, dass es andere gibt wer weiß, wie viele? -, die gerade jetzt, in diesem Moment, durch dieselben Verliese streifen wie sie, mit denselben Gegnern ringen, dieselben Tode sterben, oder ebendies zu einer früheren Zeit, in einer unbestimmten Vergangenheit getan haben. Zum einen ist es möglich, Nachrichten für seine Mitspieler zu hinterlassen, ihnen Hinweise zu geben oder Warnungen auszusprechen (oder zu versuchen, andere mit einer betrügerischen Botschaft in eine Falle $\mathrm{zu}$ locken). Des Weiteren kann es geschehen, dass man bei seinem Tod einen Blutfleck hinterlässt, der Spieler, die späterhin an den Ort dieses Sterbens kommen, auf Wunsch ein gespentisches Replay des eigenen Scheiterns sehen lässt - als eine sekundenlange Moritat über das Los, welches die Vorwitzigen und Tölpelhaften ereilt. Schließlich und vor allem sorgt DARK SOULS dafür, dass man immer wieder schattenhafter Präsenzen gewahr wird. Anfangs mag man sich wundern, was es

117 In Dylans Song „It’s Alright, Ma (I’m Only Bleeding)“ von dem Album Bringing it all back home (1965) heißt es: „Pointed threats, they bluff with scorn / Suicide remarks are torn / From the fool's gold mouthpiece / The hollow horn plays wasted words / Proves to warn that he not busy being born / Is busy dying“.

118 MacDonald/Killingsworth: Prologue, S. 6.

119 MacDonald/Killingsworth: Prologue, S. 6. 
mit diesen merkwürdigen Figuren, die scheinbar willkürlich erscheinen und wieder verschwinden, auf sich hat. Irgendwann jedoch begreift man, wie Daniel Vella schreibt,

that they are in fact other players, captured and re-presented in realtime as they engage in their own simultaneous playing of DARK SOULS wherever (and whoever) they might be in the world. The ghostly figures travel paths different to the ones the player takes; they wear armour and wield weapons the player might not yet have discovered; they deploy techniques the player might not yet have learnt, or even known were possible. In short, they shadow the player's own playing of DARK SOULS with an intimation of all the „paths not taken," revealing the vast space of possibility that is both hinted at and, simultaneously, closed off by the player's activation of a single playing-out of the game. ${ }^{120}$

Nicht zuletzt dieses jähe Aufscheinen der unzähligen Pfade, die man hätte beschreiten können und vielleicht noch - bei einem zukünftigen Durchlauf des Spiels - beschreiten wird, rückt etwas in den Blick, das Vella als „ludic sublime" bezeichnet. Aus seiner Sicht ließen sich beinah alle ästhetischen Effekte, die ich auf den vorangegangenen Seiten zu beschreiben und zu erläutern versucht habe, als Einzelaspekte dieses „ludic sublime“ konzeptualisieren. Zielt es doch darauf, „to actively remind the player of the limits and the inadequacy of her perceptual opening onto the milieu of the gameworld, the computational systems underlying it, and the space of possibilities they structure“" ${ }^{121}$

Zweifellos mag sich jemandem, der DARK SOULS spielt - oder darüber zu schreiben versucht - der Eindruck aufdrängen, Miyazaki und seine Mitarbeiter hätten „an ineffable whole“ gestaltet, das die „necessarily limited perception“ einer jeden Spielerin, eines jeden Spielers ins Unendliche übersteigt. ${ }^{122}$ Aber diese unmögliche Unendlichkeit faltet sich zugleich wieder auf den Spieler zurück, in der vielfachen, ebenso gespentischen wie konkreten Präsenz anderer „lone adventurers“, aus welcher dann die virtuelle Bruderschaft entsteht, von der Keza MacDonald spricht.

So mag es angemessen sein, den vielen Zeitlichkeiten von DARK SOULS eine weitere hinzuzufügen: die Zeitlichkeit der Assemblage. Sie geht nicht auf in dem ebenso dynamischen wie spannungsreichen In- und Gegeneinander von vektorieller und zyklischer Zeit, das die Spielerfahrung in höchstem Maße prägt; jedenfalls dann nicht, wenn man die Idee der Assemblage tatsächlich zu ihrem Recht kommen lassen will. Aus einer Perspektive, wie sie etwa Lowenhaupt

120 Daniel Vella: No Mastery Without Mystery. DARK SOULS and the Ludic Sublime. In: Game Studies 15 (2015), H. 1, http://gamestudies.org/1501/articles/vella [letzter Zugriff: 12.05.2020].

121 Vella: No Mastery Without Mystery.

122 Vgl. Vella: No Mastery Without Mystery. 
Tsing und Lötscher zu entwickeln versuchen, ließe sich vielmehr behaupten, dass die verschiedenen Mechaniken, die in DARK SOULS dazu dienen, jenen zugleich gespenstischen und konkreten Kontakt zwischen anonymen Spielerinnen und Spielern zu stiften, ihrerseits eine gespenstisch-konkrete Präsenz am Horizont des Denkens erscheinen lassen. Man berührt sich, ohne einander nahezukommen, hilft sich, ohne einander zu kennen, tut dies in einer Art zufälliger Verbindlichkeit und erfährt dabei eine Gemeinschaft, die irgendwie zugleich höchst real und völlig fiktiv ist und sich in ephemerer Flüchtigkeit immer wieder aufs Neue bildet und auflöst.

Vielleicht erfüllt sich auch hierin eine Sehnsucht unserer Zeit. 
